\title{
Nitrogen budget of the northwestern Black Sea shelf inferred from modeling studies and in situ benthic measurements
}

\author{
M. Grégoire ${ }^{1,3, *}$, J. Friedrich ${ }^{2,4}$ \\ ${ }^{1}$ FNRS Researcher Associate, MARE, University of Liège, Laboratory of Oceanology, B6c Sart Tilman, 4000 Liège, Belgium \\ ${ }^{2}$ Federal Institute of Environmental Science and Technology, Limnological Research Center, 6047 Kastanienbaum, Switzerland \\ ${ }^{3}$ Present address: Centre for Estuarine and Marine Ecology, NIOZ, PO Box 140, 4400 AC Yerseke, The Netherlands \\ ${ }^{4}$ Present address: Alfred Wegener Institute for Polar and Marine Research, Am Handelshaven 12, 27570 Bremerhaven, \\ Germany
}

\begin{abstract}
A 3D eddy-resolving coupled biogeochemical-hydrodynamical model and in situ observations are used to investigate benthic processes on the Black Sea's NW shelf. Measurements of benthic fluxes (oxygen, nutrients, redox compounds) with in situ flux chambers are analyzed in regard to sediment dynamics on the shelf. The seasonal/interannual and spatial variability of benthic processes is explained in terms of 3D ecohydrodynamics. The space/time distribution of benthic fluxes depended on the position of the river plume and the associated primary production, intensity of vertical mixing and water depth. Model results and in situ observations reveal the presence of a region of intense benthic recycling and high benthic nutrient fluxes nearshore and in the northern part of the shelf. The model estimates that this region covers about $15 \%$ of the shelf area and is connected to the high productivity and high sedimentation caused by river input of organic matter. On the offshore shelf, covering about $85 \%$ of the shelf area, benthic nutrient regeneration is low due to low productivity. Benthic mineralization pathways (aerobic respiration, denitrification, sulfate reduction, methanogenesis) are quantified. In the high flux region, more than $55 \%$ and in the offshore low flux region more than $80 \%$ of the organic matter is decomposed by aerobic respiration. In the high flux region, sulfate reduction is the main anaerobic pathway, whereas denitrification is more important on the low flux offshore shelf. At the shelf edge, under the influence of anoxic waters, more than $60 \%$ of organic matter is remineralized by sulfate reduction. Little organic matter is decomposed by methanogenesis. A mass balance of particulate organic carbon (POC) and particulate organic nitrogen (PON), integrated over the whole shelf and year, shows that 3.7 to $4.2 \times 10^{6}$ t of POC reach the sediments, while model results give a value of $1.4 \times 10^{6} \mathrm{t} \mathrm{C}$. The annual ammonium benthic outflux is estimated at $85 \times 10^{3}$ and $174 \times 10^{3} \mathrm{t} \mathrm{N}$ by in situ data and the model, respectively. The amount of nitrogen lost by burial and denitrification estimated from in situ observations is $57 \times 10^{3}$ and $324 \times$ $10^{3}$ t N, respectively. Therefore, NW shelf Black Sea sediments are an efficient sink for riverine nitrogen, trapping about $50 \%$ of the annual river discharge in total inorganic N.
\end{abstract}

KEY WORDS: Mathematical modeling $\cdot$ Coupled biogeochemical-hydrodynamical model $\cdot$ Benthic processes $\cdot$ Nitrogen cycling $\cdot$ Black Sea's northwestern shelf

\section{INTRODUCTION}

In shallow waters of continental shelves and coastal areas, a substantial part of the organic matter production in the water column is deposited on the sea floor where it is available to the benthic community. This benthic community decomposes the organic matter through a complex of reactions including hydrolysis, fermentation and oxidation into inorganic components. The nutrients resulting from benthic mineralization can diffuse back into the water column where they can be used for primary production. Consequently, benthic 
mineralization is a key factor for benthic-pelagic coupling in shallow marine ecosystems (Graf 1992), and may be important in sustaining the high productivity in the system and affecting the chemical composition of the seawater. However, so far, benthic processes are usually neglected or crudely parameterized in modeling experiments. This paper presents an attempt to assess the importance of benthic processes in the nitrogen cycling of the northwestern Black Sea continental shelf based on the analysis of in situ observations and modeling experiments.

The Black Sea's northwestern shelf is a shallow semi-enclosed area of about $50000 \mathrm{~km}^{2}$ with a volume of $4730 \mathrm{~km}^{3}$ and a water depth less than $150 \mathrm{~m}$. The mid-depth at the shelf edge is about $150 \mathrm{~m}$. It forms a receptacle for the most important Black Sea's rivers, the Danube, Dnepr and Dniestr, which together discharge $279 \mathrm{~km}^{3}$ fresh water $\mathrm{yr}^{-1}\left(212 \mathrm{~km}^{3} \mathrm{yr}^{-1}\right.$ for the Danube itself, more than $75 \%$ of the total river input into the Black Sea). Also, the shelf is well known as a region of enhanced biological production fed by the nutrients brought by the river discharges as shown by satellite images (e.g. Sur et al. 1994, Nezlin et al. 1999). The Danube receives the effluents from 10 European countries and constitutes a major source of pollutants, nutrients and organic matter (Popa 1993). Each year, the Danube discharges 6 to $8 \times 10^{5}$ t of total inorganic nitrogen and $18 \times 10^{3} \mathrm{t}$ of inorganic phosphorus (e.g. Cociasu et al. 1997). Nitrogen inputs from the Dniestr and Dnepr rivers together represent only 3\% of the Danube input. The ratio of inorganic nitrogen river discharges into the shelf on the shelf surface $\left(\sim 50000 \mathrm{~km}^{2}\right)$ is about 10 times higher than what is usually observed in the Global Ocean (surface of the global shelf: $26 \times 10^{6} \mathrm{~km}^{2}$, total river flux of dissolved nitrogen $=35 \times 10^{6} \mathrm{t} \mathrm{N} \mathrm{yr}^{-1}$; Wollast 1998). The high load of anthropogenic inorganic nutrients and organic inputs from the rivers, the small volume of the shelf water, and the strong thermohaline stratification have made the Black Sea's northwestern shelf highly sensitive to eutrophication.

In the framework of the EU project European River Ocean System-21 (EROS-21), the relationship between increased input of nutrients through the rivers and changes that occurred in the ecosystem of the Black Sea's northwestern shelf has been analyzed. Two large expeditions were conducted on the Black Sea shelf in summer 1995 and spring 1997 aboard the Ukrainian RV 'Professor Vodyanitsky'. These 2 data sets will be complemented by the results of an INTAS cruise conducted in May 1998. Measurements of benthic fluxes with in situ flux chambers during the EROS-21 and INTAS expeditions revealed large spatial differences in benthic nutrient regeneration (Friedl et al. 1998, Wijsman et al. 1999, Friedrich et al. 2002) in response to the position of the river plume and the associated primary production, the intensity of the vertical mixing and the water depth.

In this paper, modeling experiments made with a 3D eddy-resolving coupled biogeochemical-hydrodynamical model and in situ observations are jointly used to investigate benthic processes on the Black Sea's northwestern shelf. More specifically, we try to quantify the amount of organic matter that reaches the shelf sediments, to understand and quantify benthic regeneration processes and to propose a nitrogen budget for the shelf in order to assess its role as a sink for riverborn nutrients.

Here, the main findings of the Black Sea climatological ecohydrodynamics simulated by the model are described. The simulated nitrogen fluxes to and from the shelf sediments are assessed and compared with available observations. Moreover, the oxygen flux to the shelf sediments and the benthic nutrient regeneration, especially nitrogen, measured during the 3 periods of measurements are analyzed in connection with the variability of the ecohydrodynamics (e.g. river plume dynamics induced by the shelf circulation, phytoplankton bloom dynamics, intensity of the vertical mixing) simulated by the model during the periods of measurements. Further, the seasonal/interannual and spatial variability of benthic processes is analyzed and explained in terms of the variability of the ecohydrodynamics. The different pathways of benthic mineralization (e.g. aerobic respiration, denitrification, sulfate reduction, methanogenesis) in the high and low productive areas of the shelf are also quantified. In particular, the relative contribution of aerobic and anaerobic processes to the decomposition of organic matter is estimated in the different areas and during the different periods of measurements. The mass balance of particulate organic carbon (POC) and particulate organic nitrogen (PON) for the shelf is established based on in situ measurements and model results. Finally, the importance of burial and denitrification in the sediments is quantified and the role of the shelf acting as a sink for the inorganic nitrogen discharged by the rivers is estimated.

\section{MATERIALS AND METHODS}

Benthic flux measurements. Benthic fluxes of oxygen, nutrients and redox compounds were measured in 3 years during different seasons, in August 1995, May 1997 and May 1998, at almost the same locations (Fig. 1): within the Danube river plume (BS 95/8/18, BS 97/5/11, BS 98/5/5), on the Danube Prodelta (BS 95/8/20, BS 97/5/14), in the Dniestr mouth (BS 95/8/14, BS 97/5/17), on the offshore shelf (BS 97/5/19, BS 98/5/6) and at the shelf edge (BS 95/8/9, BS 95/8/22, BS 97/5/24) using a benthic flux chamber 


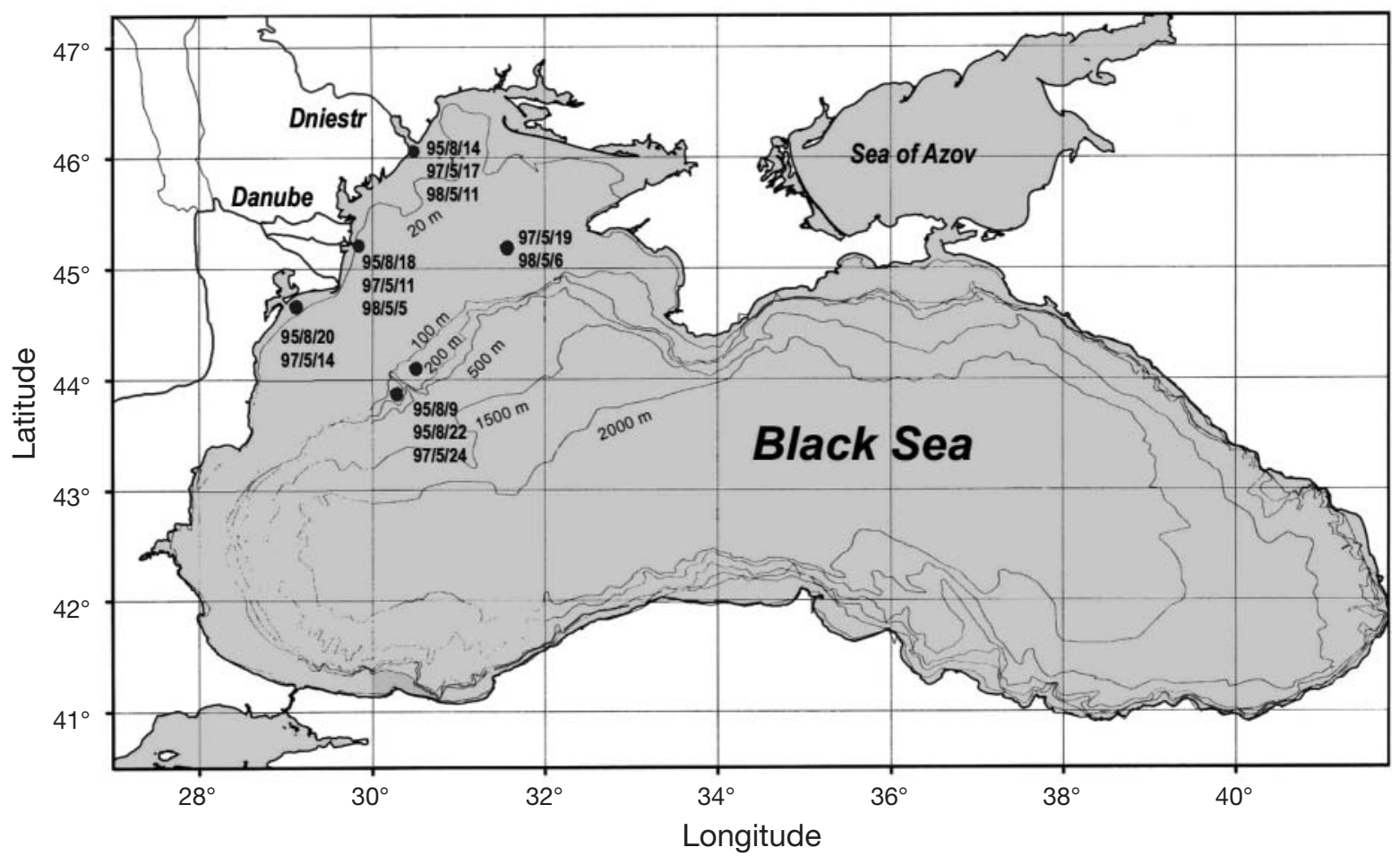

Fig. 1. Locations of the stations

lander and in situ dialysis porewater samplers. The 1995 benthic flux data were taken from Friedl et al. (1998) and those for 1997 from Friedrich et al. (2002).

The functioning of the benthic lander is described in detail in Tengberg et al. (1995) and Friedrich et al. (2002). The lander with the 2 stainless steel flux chambers was lowered to the bottom, tethered to a free floating buoy, and retrieved after $24 \mathrm{~h}$. An electronic system triggers up to 15 mechanical functions. The flux chambers were pushed into the sediment and the top lids closed after $30 \mathrm{~min}$. Spring actuated syringes were used to take 10 water samples from each flux chamber in $2 \mathrm{~h}$ intervals. During operation, the flux chambers were stirred continuously at a velocity of about $1 \mathrm{rps}$, resulting in a corresponding boundary layer thickness of about $1 \mathrm{~mm}$. In one flux chamber, the oxygen concentration and $\mathrm{pH}$ were recorded continuously by an $\mathrm{O}_{2}$ and pH sensor coupled to a Seabird Electronics sea logger unit (SBE 16).

Filtered subsamples from the syringes and the porewater cells were analyzed on board by standard colorimetric methods (Deutsche Einheitsverfahren 1998; German standard: www.wiley-vch.de/contents/dev/ devih.html) with a PROCON autoanalyzer for soluble reactive phosphate (ammonium-molybdate method) and nitrate $(2,6$ dimethylphenole method). Soluble reactive ammonium (phenolhypochlorite method) and nitrite (diazo method) were determined on board with a MERCK SQ 300 photometer. Silica was analyzed photometrical with molybdenum blue. Total iron and manganese concentrations were determined in $\mathrm{HNO}_{3}$ acidified subsamples by GF-AAS (Graphite Funnel Atomic Adsorption Spectroscopy). Benthic fluxes were calculated by fitting a linear regression to the changes in concentration versus time. Based on the concentration measurements of each compound, fluxes were calculated according to to:

$$
F=h \frac{d[C]}{\mathrm{d} t}
$$

where $h$ is the height $(\mathrm{m})$ of the enclosed water column in the flux chamber and $\mathrm{d}[\mathrm{C}] / \mathrm{d} t\left(\mathrm{mmol} \mathrm{m}^{-3} \mathrm{~d}^{-1}\right)$ represents the accumulation rate of a compound in the benthic chamber. The fluxes of the 1995 investigation were taken from Friedl et al. (1998).

To complement our measurements of oxygen fluxes with the benthic chambers and to assess the reliability of these measurements, sediment community oxygen consumption (SCOC) measured by incubation of sediment cores (Wijsman et al. 1999, Wijsman 2001) will be used for a comparison. Stainless steel flux chambers are known to artificially increase oxygen flux due to electric potential gradients along the wall of the chamber (Cramer 1989). Measurement of SCOC by deck incubation of sediment cores has the disadvantage of provoking disturbances due to subsampling, temperature shock, pressure difference and possibility of contamination of the bottom water with airborne oxygen (Wijsman 2001). However, comparison of the oxygen 
fluxes by both methods shows quite good agreement, with flux chamber values being lower in most cases. We therefore conclude that the values from both methods are reliable. Oxygen uptake rates from both methods provide an estimate for the total depth-integrated rate of benthic mineralization when by far the largest part of organic matter is decomposed by aerobic respiration and all reduced substances diffusing from the sediment are oxidized. Since these conditions were met at the offshore shelf in spring 1997 and 1998 only, we have to consider that part of the oxygen has been consumed to oxidize reducing substances at the other locations. At BS 98/5/5 Danube Delta Front, at least $3 \%$, and at the BS $97 / 5 / 17$ Dniestr mouth, about $2 \%$ of the total oxygen consumption might have been used for nitrification, for example. However, by far the largest influence on the oxygen consumption besides aerobic microbial decomposition of organic matter is due to the activity of zoobenthos. Therefore, the measured oxygen consumption has to be regarded as an upper limit with respect to the microbial decomposition of organic matter. Wijsman et al. (1999) reported that $21 \%$ of the total oxygen consumption on the Black Sea shelf was consumed by macrobenthos. We suspect that at the offshore shelf in the well-oxygenated bottom water where filter-feeding bivalves (Mytilus galloprovincialis) occur in dense patches an even higher percentage might have been related to macrobenthos activity.

We use diffusive fluxes of nutrients calculated from porewater profiles to estimate the intensity of the benthic recycling at Stn BS 98/5/11 (Dniestr mouth) since the flux chamber experiment in 1998 failed at that particular station. Porewater profiles were obtained from in situ dialysis porewater samplers. Design and deployment are described in detail in Urban et al. (1997).

Diffusive benthic fluxes based on porewater profiles were calculated by applying Fick's first law (Lerman 1979).

$$
J=-\phi D_{s} \frac{d C}{d x}
$$

where $J$ is the flux ( $\mathrm{mmol} \mathrm{m} \mathrm{m}^{-2} \mathrm{~d}^{-1}$ ) and $\phi$ is the porosity $\left(\mathrm{ml} \mathrm{cm}{ }^{-3}\right)$. The effective diffusion coefficient $D_{\mathrm{s}}$ in the sediments was approximated as:

$$
D_{s}=\frac{D}{\phi F}
$$

where $D$ is the molecular diffusion coefficient in seawater at $5^{\circ} \mathrm{C}$ (Furrer \& Wehrli 1996). $F$ is the sediment resistivity (Berner 1980, Christensen et al. 1987) and is given by an empirical relationship to $\phi$ (Manheim 1970):

$$
F=\frac{1}{\phi^{m}}
$$

For sediments of high porosities $>0.7, \mathrm{~m}$ is approximately 3 (Ullman \& Aller 1982). Sediment porosity was measured during the 1997 cruise (Wijsman et al. 1999).

Particle accumulation rates and the accumulation of POC and PON in the sediments were calculated according to:

$$
\omega=R(1-\phi) \rho_{s}
$$

where $\omega$ is the accumulation rate in $\mathrm{g} \mathrm{cm}^{-2} \mathrm{yr}^{-1}, R$ the sedimentation rate in $\mathrm{cm} \mathrm{yr}^{-1}, \phi$ the sediment porosity (0.85) and $\rho_{\mathrm{s}}$ the density of the sediment in $\mathrm{g} \mathrm{cm}^{-3}$. Sedimentation rates were taken from Gulin et al. (1997) for the Danube Delta Front $\left(1 \mathrm{~cm} \mathrm{yr}^{-1}\right)$, the offshore area $\left(0.04 \mathrm{~cm} \mathrm{yr}^{-1}\right)$ and the western shelf slope $\left(0.22 \mathrm{~cm} \mathrm{yr}^{-1}\right)$. Sediment composition of surface sediments at the sampled station was taken from Reschke (1999). The error of the sedimentation rates is about $14 \%$, the error of the sediment components ranges between 2.9 and $7.7 \%$. The SD of the accumulation of POC and PON in the sediment was calculated by error propagation.

Gross sedimentation of POC and PON was estimated from the accumulation of POC and PON in the sediment and the decomposition rate of organic matter, calculated from measured benthic uptake or outflux of oxygen, nitrate, manganese, iron, sulfate and methane according to idealized diagenetic reactions (aerobic respiration, nitrate reduction/denitrification, manganese reduction, iron reduction, sulfate reduction, methanogenesis; Aller 1982). The SD of the averaged gross sedimentation of POC and PON and organic matter decomposition (calculated from the stations in Table 3) account for 34 and $44 \%$ in the high and low flux regions, respectively.

GeoHydrodynamics and Environment Research (GHER) modeling. The GHER 3D eddy-resolving coupled hydrodynamical-biogeochemical model has been used to simulate the seasonal and mesoscale ecohydrodynamics and in particular, to simulate the strong non-linear behavior of regions influenced by the river plume during the periods of measurements. This model is 3D, non-linear, baroclinic and uses a refined turbulent closure scheme defined by the kinetic energy of the turbulence and an algebraic mixing length taking into account the intensity of both the stratification and the surface wind mixing. The whole basin $\left(27.15^{\circ}\right.$ to $42.64^{\circ} \mathrm{E}, 40.61^{\circ}$ to $\left.46.68^{\circ} \mathrm{N}\right)$ is covered by a $5 \times 5 \mathrm{~km}$ horizontal numerical grid and 25 vertical layers. The biogeochemical model describes the nitrogen cycling through the pelagic and benthic food web and is described by 6 aggregated state variables: phytoplankton and zooplankton biomass without reference to species, total detritus (lumping together dissolved and particulate dead organic matter), nitrate, ammonium and benthic detritus (Fig. 2). The mathematical formulation of the biogeochemical interactions is given in Table 1 and the parameters are listed in Table 2. The structure and parameterization of the 


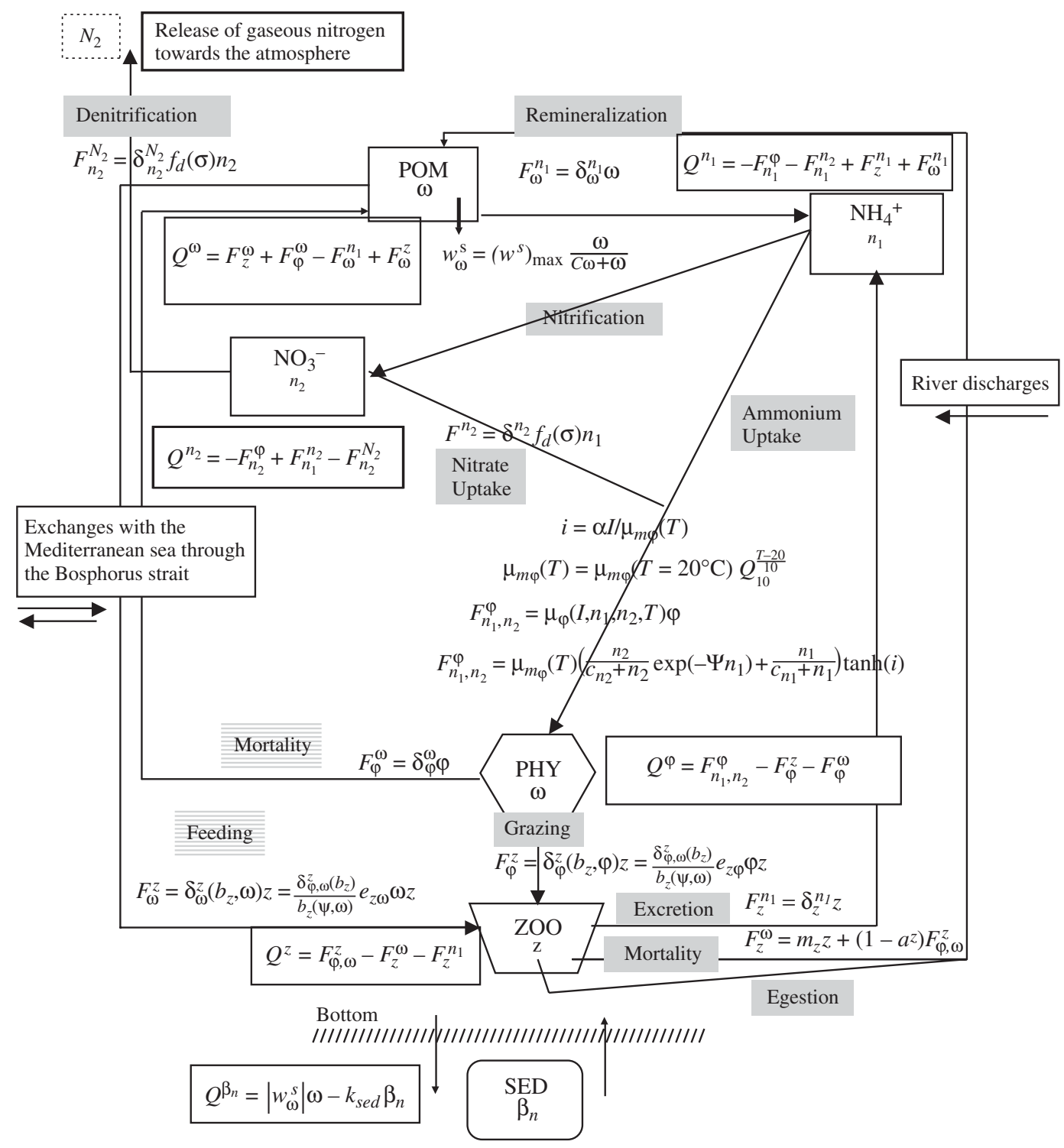

Fig. 2. The ecosystem model. All the interaction terms are written on the arrows and are described in Tables $1 \& 2 . F_{i}^{j}$ is the nitrogen flux issued from the state variable $i$ and going to the state variable $j . Q^{y}$ is the production/destruction term of the biogeochemical state variable $y$

biogeochemical model are described in extenso in Grégoire et al. (2001).

Moreover, following the theory developed by Delhez et al. (2001), differential equations for computing the age of a passive tracer released at the Danube's mouth have been added to the general equations of the coupled model. The Danube discharge and the daily winds encountered during the 3 expeditions have been used to force the model, while temperature and salinity values are relaxed towards climatological values at the surface. The wind data have been taken from the meteorological observations on board ship during the cruises.

The results of the biogeochemical model are described in detail in Grégoire et al. (2004). In Gregoire
\& Lacroix (2003), they are used for diagnostic computation and, in particular, to compute the exchanges of nitrogen between the shelf and offshore. In this paper, the simulated benthic fluxes are compared with in situ observations in order to assess the capacity of the model in simulating the exchanges between the pelagic ecosystem and the bottom. The measurements performed during the EROS-21 and INTAS expeditions are analyzed and interpreted in terms of the variability of the ecohydrodynamics simulated by the coupled model. Then, a tentative of establishing a nitrogen budget of the shelf is presented using model results and in situ measurements. 
Table 1. Mathematical formulation of biogeochemical processes

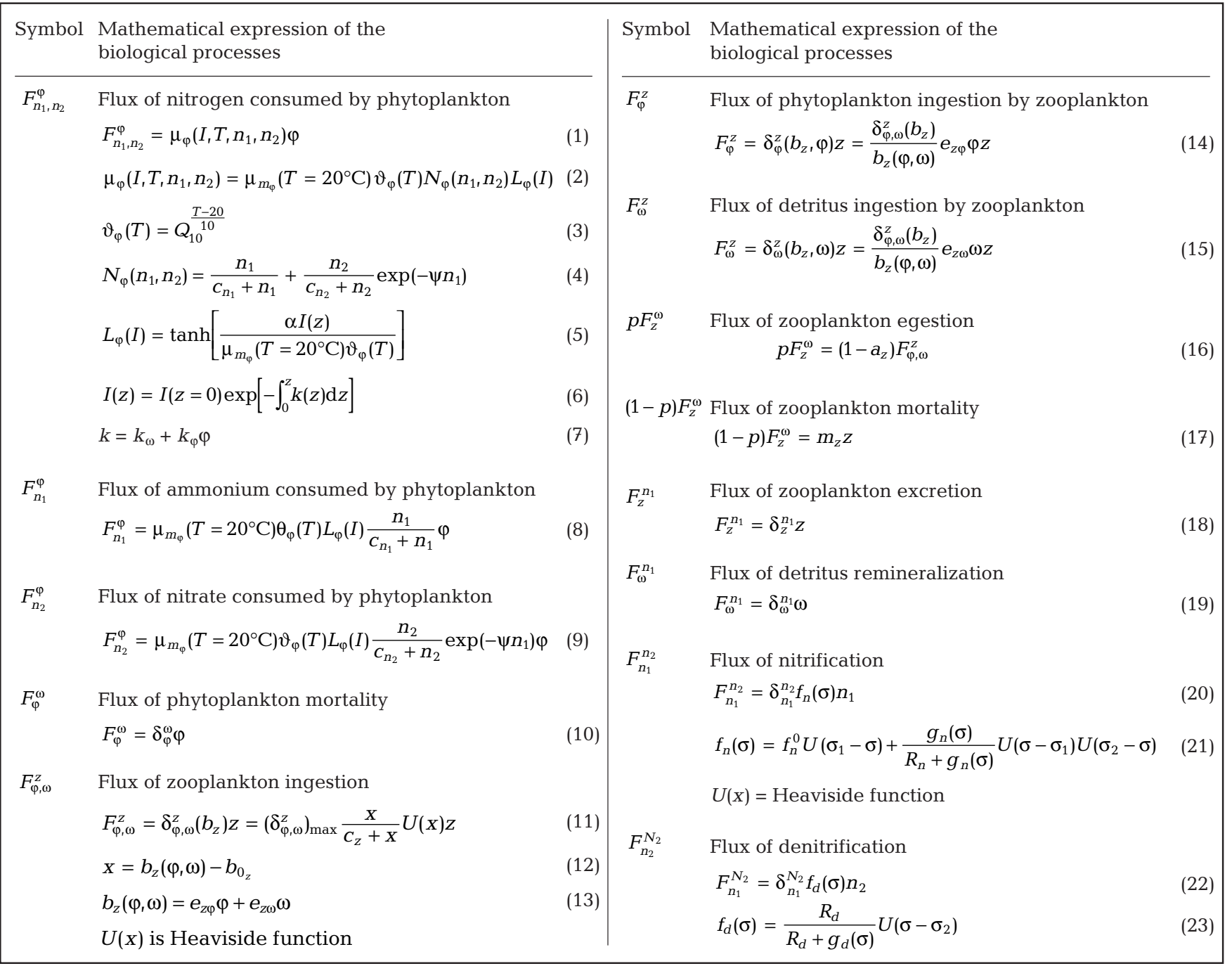

\section{RESULTS}

\section{Climatological year: model results}

\section{Ecohydrodynamics}

The space-time variability of the northwestern shelf primary production is essentially determined by the variations of the spreading of the Danube's outflow, and thus by the hydrodynamics of the shelf. Due to the small mechanical inertia of a shallow water column, the circulation of the Black Sea's northwestern shelf exhibits large temporal and spatial changes in response to the intrusion of the fresh river water, the large variability of meteorological conditions (e.g. the atmospheric temperatures vary from near freezing values in winter to more than $20^{\circ} \mathrm{C}$ in summer), the abrupt variations of the bathymetry at the shelf break and the interactions with the open sea circulation. Fig. 3 illustrates the seasonal evolution of the general circulation and associated mesoscale structures and salinity patterns during a mean climatological year. Fresh river waters discharged by the Danube, Dniestr and Dnepr are separated from the open seawater by a strong haline front. A salinity value below 17 can be used to trace this water mass enriched in river nutrients (e.g. Ragueneau et al. 2002). The circulation exhibits pronounced seasonal variability, being cyclonic at low river discharges and strong northerly winds and anticyclonic at high river discharges and moderate northerly winds. Also, the shelf circulation simulated by the model for a climatological year is cyclonic and the Danube's discharges are transported southwards from the end of fall until early spring when strong northerly winds prevail. River waters are confined along the western coast by a strong haline front. At 
Table 2. Description, values and units of the parameters used in the formulation of biological interaction terms

\begin{tabular}{|c|c|c|c|}
\hline Parameters & Description & Units & Value \\
\hline \multicolumn{4}{|l|}{ Phytoplankton } \\
\hline$\mu_{m_{\varphi}}\left(T=20^{\circ} \mathrm{C}\right)$ & Growth rate at $20^{\circ} \mathrm{C}$ & $d^{-1}$ & 3 \\
\hline$Q_{10}$ & $Q_{10}$ factor & - & 1.88 \\
\hline$c_{n_{1}}$ & Half-saturation constant for ammonium uptake & $\mathrm{mmol} \mathrm{N} \mathrm{m}^{-3}$ & 0.2 \\
\hline$C_{n_{2}}$ & Half-saturation constant for nitrate uptake & $\mathrm{mmol} \mathrm{N} \mathrm{m}^{-3}$ & 0.5 \\
\hline$\Psi^{2}$ & Constant of inhibition of nitrate uptake by the presence of ammonium & $\left(\mathrm{mmol} \mathrm{N} \mathrm{m}^{-3}\right)^{-1}$ & 1.46 \\
\hline$\alpha$ & Photosynthetic efficiency & $\left(\mathrm{W} \mathrm{m} \mathrm{m}^{-2}\right)^{-1} \mathrm{~d}^{-1}$ & 0.015 \\
\hline$k_{\omega}$ & Pure water diffusive attenuation coefficient & $\mathrm{m}^{-1}$ & 0.08 \\
\hline$k_{\varphi}$ & Phytoplankton attenuation coefficient & $\left.\mathrm{m}^{-1}(\mathrm{mmol} \mathrm{N} \mathrm{m})^{-3}\right)^{-1}$ & 0.07 \\
\hline$\delta_{\varphi}^{\omega}$ & Mortality rate & $\mathrm{d}^{-1}$ & 0.05 \\
\hline \multicolumn{4}{|l|}{ Zooplankton } \\
\hline $\begin{array}{l}\left(\mathcal{O}_{\varphi, \omega}\right)_{\max } \\
a_{z}\end{array}$ & $\begin{array}{l}\text { Maximum grazing rate } \\
\text { Assimilation efficiency }\end{array}$ & $\begin{array}{l}d^{2} \\
-\end{array}$ & 0.9 \\
\hline$C_{z}$ & Half saturation constant for ingestion & $\mathrm{mmol} \mathrm{N} \mathrm{m}^{-3}$ & 0.5 \\
\hline$b_{0_{z}}$ & Threshold concentration & $\mathrm{mmol} \mathrm{N} \mathrm{m}^{-3}$ & 0.6 \\
\hline$e_{z \varphi}$ & Capture efficiency of phytoplankton & - & 0.7 \\
\hline$e_{z \omega}$ & Capture efficiency of detritus & - & 0.5 \\
\hline$\delta_{z}^{n_{1}}$ & Excretion rate & $\mathrm{d}^{-1}$ & 0.1 \\
\hline$m_{z}$ & Mortality rate & $d^{-1}$ & 0.05 \\
\hline \multicolumn{4}{|c|}{ Nitrification and denitrification } \\
\hline$\delta_{n_{1}}^{n_{2}}$ & Maximum nitrification rate & $d^{-1}$ & 0.1 \\
\hline$R_{n}$ & $\begin{array}{l}\text { Half-saturation constant for the limitation function of the nitrification } \\
\text { process by the availability of oxygen }\end{array}$ & $\mathrm{mmol} \mathrm{O}_{2} \mathrm{~m}^{-3}$ & 10 \\
\hline$f_{n}^{0}$ & $\begin{array}{l}\text { Value of the limitation function of the nitrification process by the } \\
\text { availability of oxygen in surface waters }\end{array}$ & - & 0.87 \\
\hline$\sigma_{1}$ & Density of the oxycline upper boundary & $\mathrm{kg} \mathrm{m}^{-3}$ & 14.8 \\
\hline$\sigma_{2}$ & $\begin{array}{l}\text { Density above which the nitrification process ceases due to oxygen } \\
\text { deficiency and the denitrification process starts to occur }\end{array}$ & $\mathrm{kg} \mathrm{m}^{-3}$ & 15.6 \\
\hline$\delta_{z_{2}}^{N_{2}}$ & Maximum denitrification rate & $\mathrm{d}^{-1}$ & 0.015 \\
\hline$R_{d}$ & $\begin{array}{l}\text { Constant used in the inhibition function of the denitrification rate by } \\
\text { the presence of oxygen }\end{array}$ & $\mathrm{mmol} \mathrm{O}_{2} \mathrm{~m}^{-3}$ & 2.5 \\
\hline \multicolumn{4}{|l|}{ Detritus } \\
\hline & Remineralization rate & $\mathrm{d}^{-1}$ & 0.07 \\
\hline$\left(W_{s}^{\omega}\right)_{\max }$ & Maximum detrital sinking velocity & $\mathrm{m} \mathrm{d}^{-1}$ & 8 \\
\hline$C_{\omega}$ & Half-saturation constant used in the expression of the detritus sinking rate & $\mathrm{mmol} \mathrm{N} \mathrm{m}{ }^{-3}$ & 0.2 \\
\hline $\begin{array}{l}\text { Benthic detritus } \\
k_{\text {sed }}\end{array}$ & Benthic detritus remineralization rate & $\mathrm{d}^{-1}$ & 0.03 \\
\hline
\end{tabular}

high river discharges and moderate northerly wind conditions (roughly from April to May until November), the Danube's discharges are trapped in an anticyclonic gyre and are transported to the north of the shelf before flowing southwards towards the open sea (Fig. 3). Although the exact location of this anticyclonic gyre varies seasonally according to the intensity of the river discharges and of the wind pattern, it is very robust and present almost throughout the year. In spring, it is located off the Danube's delta (Fig. 3a); in summer, it extends and moves towards the southeastern part of the shelf and reaches the shelf break at the end of August (Fig. 3c). During the year, the frontal interface undergoes important seasonal modification in its form and position, and exhibits, especially in summer when it reaches the shelf break, instabilities manifested by the generation and ejection of filaments contributing to the exchanges between the shelf and offshore (Fig. 3d). It is due to this type of mesoscale/ submesoscale instabilities that shelf waters propagate its properties to the deep basin and affect its ecosystem functioning. It should be noted that this climatological pattern of the shelf circulation may show important variations induced by particular winds and river discharges conditions as shown by Oguz et al. (2002) comparing the summers 1998 and 1999.

The annual cycle of the Black Sea's primary production is described in extenso in Gregoire et al. (2001) and is compared with SeaWiFS satellite observations. Here below, the main features of the shelf ecodynamics are described and the simulated benthic fluxes are analyzed and compared with available observations. 

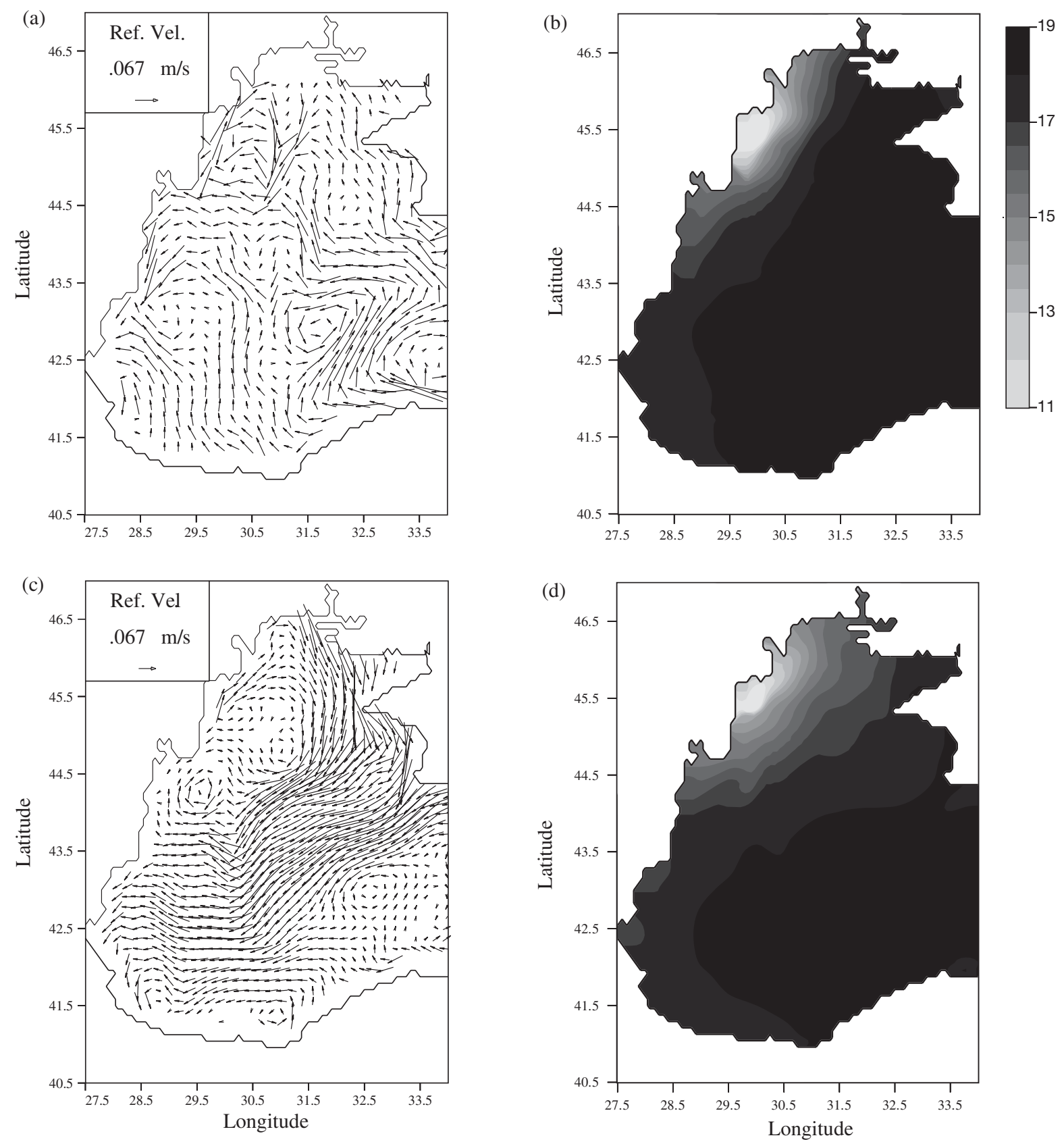

Fig. 3. Seasonal evolution of the climatological mean pattern of the Black Sea's general circulation $(a, c)$ and salinity pattern $(b, d)$ simulated at the surface in April $(\mathrm{a}, \mathrm{b})$ and in August $(\mathrm{c}, \mathrm{d})$

The northwestern shelf is the most productive area of the Black Sea basin and is classified as a eutrophic area (e.g. Nezlin et al. 1999). With a model estimated primary productivity of $220 \mathrm{gC} \mathrm{m}^{-2} \mathrm{yr}^{-1}$ and a total production of $10^{7} \mathrm{t} \mathrm{C} \mathrm{yr}^{-1}$ (Gregoire \& Lacroix 2003), it contributes $23 \%$ of the total basin-wide primary production of $5 \times 10^{7} \mathrm{t} \mathrm{C} \mathrm{yr}^{-1}\left(130 \mathrm{~g} \mathrm{C} \mathrm{m}^{-2} \mathrm{yr}^{-1}\right)$. In the river plume, the water column is strongly stratified throughout the year (in winter, the mixed layer depth is lower than $20 \mathrm{~m}$ ) and continuously enriched in nutrients allowing a permanent growth of the phytoplankton at nutrient saturation conditions with seasonal modifications in the bloom intensity. These highly productive waters are separated by a strong haline front from less productive more saline offshore waters. In winter, the nutrient-rich and high productivity river waters of the northwestern shelf are transported southwards by the main cyclonic current and lead to phytoplankton blooms along the western and southwestern coasts. At the end of spring, the reversal of the current on the 
northwestern shelf transports the phytoplankton populations in the northeastern part of the shelf. Due to the anticyclonic pattern of the shelf circulation, it is usually only in August to September that most of the nutrientrich and high plankton concentrations shelf waters reach the shelf break and penetrate into the western basin. However, model results have shown that this penetration occurs mainly at a depth of about 70 to $80 \mathrm{~m}$ (Gregoire et al. 2001).

\section{Benthic fluxes}

Since the bottom water in the abyssal part of the Black Sea is anoxic, most of the benthic fauna is restricted to the continental shelf area (e.g. Wijsman et al. 1999). The transfer of organic matter from the water column to the benthic boundary layer by sedimentation is enhanced on the shelf due to the shallow depth and the intense production of organic matter. However, on the northwestern shelf the winter meteorological conditions are the most severe with near freezing sea surface temperatures and strong northerly winds which generate high vertical turbulence levels. The water column outside the river plume is completely mixed in winter, preventing the deposition of organic matter on the bottom but favoring resuspension of particles. The fraction of organic matter which is produced in the water column and is deposited on the sea floor where it is available to the benthic community depends, of course, on the residence time of the organic matter in the water column, which is, among others related to water depths (e.g. Hargrave 1973). The fraction of the Black Sea's shelf primary production that reaches the sediments is estimated to be $12 \%$ by the model (Gregoire \& Lacroix 2003).

The spatial distribution of organic matter in marine sediments reflects the distribution of primary production with an amplification factor related to the depth of the water column (e.g. Heip et al. 1995). Various empirical relations have been suggested to describe the ratio between the carbon flux to the sediment $\left(\mathrm{C}_{\text {flux }}\right)$ and the primary production in the water column $\left(\mathrm{C}_{\text {prod }}\right)$ to the water depth for shallow estuaries and coastal waters. Fig. 4 illustrates the $\mathrm{C}_{\text {flux }}$ to $\mathrm{C}_{\text {prod }}$ ratio as a function of water depth obtained from model results assuming an algal carbon to nitrogen atomic ratio of $\sim 8.5$ for the living organic matter and of 9.1 for the rapidly sinking detrital matter (indeed, from sediment analysis on the northwestern shelf, Wijsman et al. [1999] have found that the organic matter remineralized in the sediments has a C:N atomic ratio varying between 8.8 and 15.36 with a mean value of 9.1). The bottom topography used in the model is taken from the UNESCO bathymetric map and discretized with the model resolution. Also, in the model, the lowest depth of the shelf is $80 \mathrm{~m}$ (the shelf bathymetry varies between 80 and $150 \mathrm{~m}$ ), which is an overestimation of the real depth. This picture shows that the flux of organic matter reaching the benthic layer represents 5 to $37 \%$ of the primary production in agreement with in situ observations obtained in the Black Sea (Wijsman 2001). These last values are slightly higher than empirical estimations obtained for continental slopes and deep-sea environments which are around 5 to $20 \%$ (e.g. Betzer et al. 1984, Martin et al. 1987).

Fig. 5 compares the variation with the water depth of the annual nitrogen flux to the sediments simulated by the model and obtained using the model proposed by Wijsman (2001) that is globally applicable for marine systems ranging from shallow estuaries and coastal seas to the deep ocean. The relationship proposed by Wijsman (2001) was derived by curve fitting of a conceptual model using a comprehensive data base of $\mathrm{SCOC}$ recordings derived from the literature:

$$
\begin{aligned}
\mathrm{SCOC}= & (1-0.14) \cdot 27 \cdot \exp (-0.017 \cdot Z) \\
& +0.14 \cdot 27 \cdot \exp (-0.00047 \cdot Z)
\end{aligned}
$$

where SCOC is the sediment community oxygen consumption $\left(\mathrm{mmol} \mathrm{O}_{2} \mathrm{~m}^{-2} \mathrm{~d}^{-1}\right)$ and $Z$ is the water depth (m). The first and second terms of the left-hand side of Eq. (6) represent the part of the primary production that reaches the sediment by turbulent mixing and settling, respectively. A good agreement between model results and Eq. (6) is found although the model slightly overestimates the nitrogen flux at all depths in comparison to the general formulation. Nitrogen fluxes to the sediments are between 0.732 and $1.28 \mathrm{mmol} \mathrm{N} \mathrm{m}^{-2}$ $\mathrm{d}^{-1}$ which is in very good agreement with in situ data (as shown later).

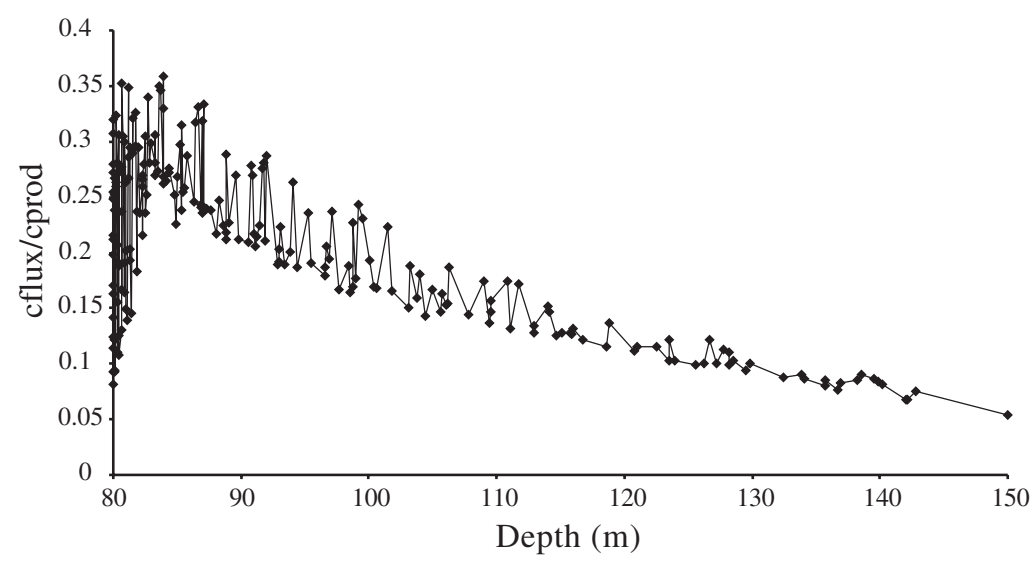

Fig. 4. Carbon fluxes $\left(\mathrm{C}_{\text {flux }}\right)$ relative to primary production $\left(\mathrm{C}_{\text {prod }}\right)$ as a function of the depth of the water column according to model results 


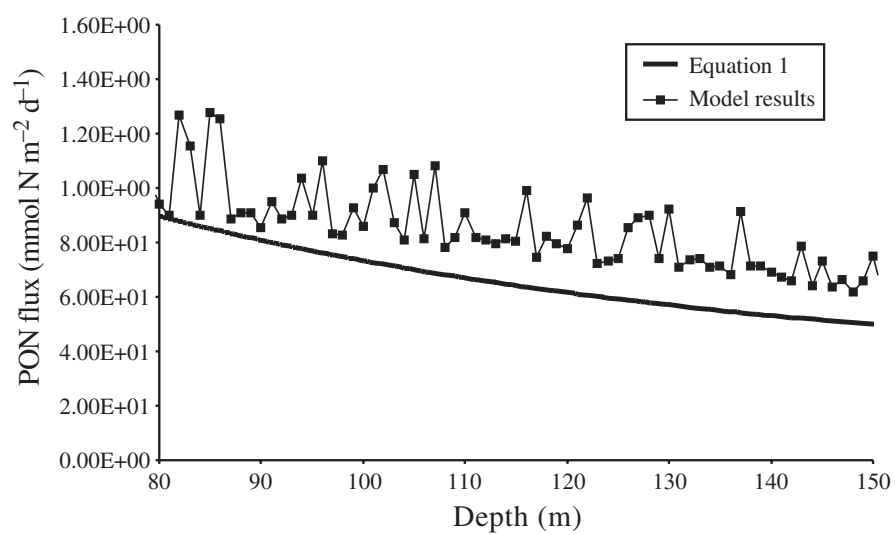

Fig. 5. Total annual PON flux to the Black Sea's northwestern shelf sediments (in mmol $\mathrm{N} \mathrm{m}^{-2} \mathrm{~d}^{-1}$ ), as a function of the water depth computed with model results and using Eq. (6) assuming a respiration coefficient of 0.85 and a $C: N$ atomic ratio of 9.1

Fig. 6 shows the annual cycle for a climatological year of the PON flux to the sediment and of the ammonium flux from the sediment (mean values for the year and shelf). The PON flux presents one main peak after the winter bloom with a value of $1.48 \mathrm{mmol} \mathrm{N} \mathrm{m} \mathrm{N}^{-2} \mathrm{~d}^{-1}$. In August, the mean value is $0.73 \mathrm{mmol} \mathrm{N} \mathrm{m}^{-2} \mathrm{~d}^{-1}$. The simulated benthic ammonia release from the sediments presents a maximum in spring after the winter bloom with a daily mean value of $1.2 \mathrm{mmol} \mathrm{N} \mathrm{m}^{-2} \mathrm{~d}^{-1}$ and a minimum in winter with a value of $0.152 \mathrm{mmol} \mathrm{N} \mathrm{m}^{-2} \mathrm{~d}^{-1}$. In summer, the model gives a value of $0.82 \mathrm{mmol} \mathrm{N} \mathrm{m}^{-2} \mathrm{~d}^{-1}$. These values are in a good agreement with the EROS-21 observations which are between 0.13 and $1.7 \mathrm{mmol} \mathrm{N} \mathrm{m}^{-2} \mathrm{~d}^{-1}$ in spring 1997 and 0.1 to $4.5 \mathrm{mmol} \mathrm{N} \mathrm{m}^{-2} \mathrm{~d}^{-1}$ in summer 1995 (Friedrich et al. 2002).

The PON fluxes to the sediment computed by the model and obtained from the analysis of in situ observations are presented in Table 3 for the different periods and areas of measurements. Model results show that the highest fluxes are observed in the Danube Delta Front and in the northern part of the shelf (at the Dniestr mouth) with values of 2.8 to 4.32 and 2.67 to $3.45 \mathrm{mmol} \mathrm{N} \mathrm{m}^{-2} \mathrm{~d}^{-1}$, respectively, which are in agreement with in situ observations which generated respective values of 5.25 to 6.31 and 2.25 to $3.63 \mathrm{mmol} \mathrm{N} \mathrm{m}^{-2} \mathrm{~d}^{-1}$. In the region of the Danube Prodelta, model results give values of 5 and $1.94 \mathrm{mmol} \mathrm{N} \mathrm{m}^{-2} \mathrm{~d}^{-1}$ for respectively spring and summer against 4.08 and $2.5 \mathrm{mmol} \mathrm{N} \mathrm{m}^{-2} \mathrm{~d}^{-1}$ for the observations. On the continental shelf, the model seems to underestimate the PON sediment flux with values around 0.01 to $0.69 \mathrm{mmol} \mathrm{N} \mathrm{m}^{-2} \mathrm{~d}^{-1}$ in 1998 (3.08 for the data); while, in 1997, the agreement is quite good with values of 0.27 to 1.72 against 1.81 in the data.

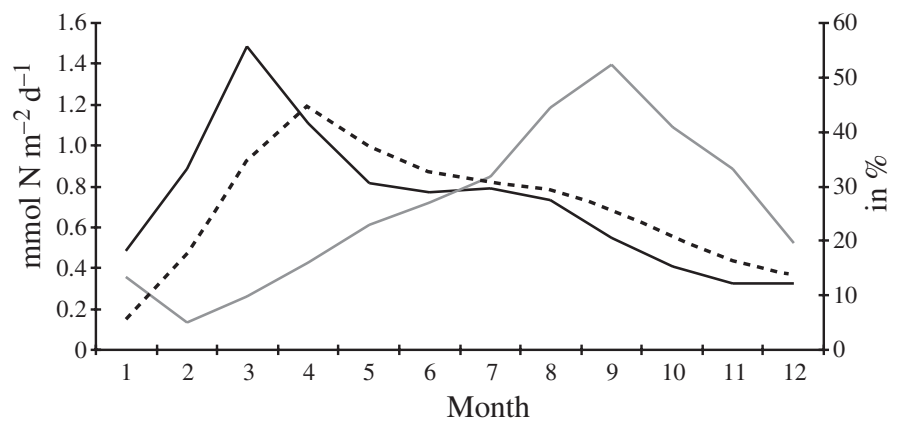

Fig. 6. Seasonal variations simulated by the model of the PON flux reaching the sediments (continuous black line, in mmol $\mathrm{N}$ $\mathrm{m}^{-2} \mathrm{~d}^{-1}$ ), the ammonia benthic outflux (dashed line, in mmol $\mathrm{N}$ $\mathrm{m}^{-2} \mathrm{~d}^{-1}$ ) (mean values for the year and the shelf) and the ratio between the sediment ammonia release and the total Danube's nitrogen discharge (gray line, in \%)

\section{Spring 1997: model results and in situ measurements}

Ecohydrodynamics

During spring 1997, the Danube plume exhibited highly variable hydrodynamic conditions with rapid modifications of the West-East extension of the haline front and of the residence time of the river plume. Indeed, the period from April to May 1997 was characterised by 2 very contrasting meteorological conditions, winter and early spring. Winter conditions with low water temperatures and strong winds were encountered during the first half of April, whereas spring conditions prevailed during the rest of the expedition. By early April 1997, the registered wind stress was about 1 order of magnitude stronger than the mean climatological wind stress of April. The wind blew from the north-east and east with a speed ranging from 10 to $18 \mathrm{~m} \mathrm{~s}^{-1}$. These intense northeastern winds prevented the reversal of the flow, usually observed at this period, and the Danube waters were directly transported towards the south by a strong jet flowing along the western coast of the basin (Fig. 7a). From 16 until 20 April, the wind reversed and blew from the south-west with a speed ranging from 4 to $11 \mathrm{~m} \mathrm{~s}^{-1}$ (average $6.8 \mathrm{~m} \mathrm{~s}^{-1}$ ). The model shows that the strong wind stresses, observed up to April 20, and their rapid variability generated intense mixing at the Danube's mouth. The mixing of low salinity river waters with marine waters was rapid and the frontal interface was located close to the coast (Fig. 7b). As a result, comparison of Figs. $3 b \& 7 b$ shows that the West-East extension of the river plume was strongly reduced in spring 1997 in comparison with the typical situation observed in April. During this period, a passive tracer released at the Danube's mouth reached isohaline 17 in less than $2 \mathrm{~d}$. 
Table 3. POC and PON gross sedimentation estimated from in situ measurements and model results (in the model, the sediment compartment is only represented on the shelf where the depth is lower than $150 \mathrm{~m}$, this explains why we do not have model results at the shelf edge). POC and PON burial in the sediment and decomposition of organic carbon in mmol m $\mathrm{m}^{-2} \mathrm{~d}^{-1}$ deduced from in situ measurements. The error calculated with error propagation is given for each flux and accounts for errors related to the sedimentation rate, errors related to the benthic flux calculation and analytical errors

\begin{tabular}{|c|c|c|c|c|c|c|c|c|}
\hline Stn & Latitude & Longitude & $\begin{array}{c}\text { POC gross } \\
\text { sedimentation } \\
\left(\mathrm{mmol} \mathrm{m}^{-2} \mathrm{~d}^{-1}\right)\end{array}$ & $\begin{array}{c}\text { POC } \\
\text { burial } \\
\left(\mathrm{mmol} \mathrm{m}^{-2} \mathrm{~d}^{-1}\right)\end{array}$ & $\begin{array}{c}\text { PON gross } \\
\text { sedimentation } \\
\left(\mathrm{mmol} \mathrm{m}^{-2} \mathrm{~d}^{-1}\right)\end{array}$ & $\begin{array}{l}\text { PON flux to sediments: } \\
\text { model results } \\
\left(\mathrm{mmol} \mathrm{m}^{-2} \mathrm{~d}^{-1}\right)\end{array}$ & $\begin{array}{c}\text { PON } \\
\text { burial } \\
\left(\mathrm{mmol} \mathrm{m}^{-2} \mathrm{~d}^{-1}\right)\end{array}$ & $\begin{array}{c}\text { Organic matter } \\
\text { decomposition } \\
\left(\mathrm{mmol} \mathrm{C} \mathrm{m}^{-2} \mathrm{~d}^{-1}\right)\end{array}$ \\
\hline \multicolumn{9}{|c|}{ Danube river plume } \\
\hline BS $98 / 5 / 5$ & $45^{\circ} 12.17^{\prime} \mathrm{N}$ & $29^{\circ} 50.79^{\prime} \mathrm{E}$ & $57.40 \pm 7.55$ & $8.90 \pm 1.28$ & $6.31 \pm 1.28$ & 2.9 & $1 \pm 0.16$ & $48.50 \pm 7.41$ \\
\hline BS $97 / 5 / 11$ & $45^{\circ} 12.17^{\prime} \mathrm{N}$ & $29^{\circ} 50.79^{\prime} \mathrm{E}$ & $47.74 \pm 8.80$ & $8.90 \pm 1.28$ & $5.25 \pm 1.41$ & 4.32 & $1 \pm 0.16$ & $38.84 \pm 8.7$ \\
\hline BS 95/8/18 & $45^{\circ} 12.17^{\prime} \mathrm{N}$ & $29^{\circ} 50.79^{\prime} \mathrm{E}$ & $48.82 \pm 7.67$ & $8.90 \pm 1.28$ & $5.37 \pm 1.25$ & 2.8 & $1 \pm 0.16$ & $39.92 \pm 4.34$ \\
\hline \multicolumn{9}{|c|}{ Dniestr mouth } \\
\hline BS $97 / 5 / 17$ & $46^{\circ} 02.93^{\prime} \mathrm{N}$ & $30^{\circ} 29.36^{\prime} \mathrm{E}$ & $20.45 \pm 6.24$ & $1.06 \pm 0.34$ & $2.25 \pm 0.48$ & 2.67 & $0.15 \pm 0.02$ & $19.39 \pm 3.62$ \\
\hline BS 95/8/14 & $46^{\circ} 02.93^{\prime} \mathrm{N}$ & $30^{\circ} 29.36^{\prime} \mathrm{E}$ & $33.06 \pm 6.48$ & $1.06 \pm 0.34$ & $3.63 \pm 0.50$ & 3.45 & $0.15 \pm 0.02$ & $32.00 \pm 3.47$ \\
\hline \multicolumn{9}{|c|}{ Continental shelf } \\
\hline BS $98 / 5 / 6$ & $44^{\circ} 53.00^{\prime} \mathrm{N}$ & $31^{\circ} 52.00^{\prime} \mathrm{E}$ & $28.04 \pm 4.30$ & $1.18 \pm 0.17$ & $3.08 \pm 0.70$ & $0.012-0.69$ & $0.17 \pm 0.03$ & $26.86 \pm 1.2$ \\
\hline BS $97 / 5 / 19$ & $45^{\circ} 09.73^{\prime} \mathrm{N}$ & $31^{\circ} 02.96^{\prime} \mathrm{E}$ & $16.43 \pm 2.38$ & $1.18 \pm 0.17$ & $1.81 \pm 0.38$ & $0.27-1.72$ & $0.17 \pm 0.03$ & $15.25 \pm 0.4$ \\
\hline \multicolumn{9}{|c|}{ Danube Prodelta } \\
\hline BS $97 / 5 / 14$ & $44^{\circ} 35.04^{\prime} \mathrm{N}$ & $29^{\circ} 11.32^{\prime} \mathrm{E}$ & $37.16 \pm 4.88$ & $7.40 \pm 1.08$ & $4.08 \pm 0.79$ & 5 & $0.78 \pm 0.12$ & $29.76 \pm 2.86$ \\
\hline BS 95/8/20 & $44^{\circ} 35.04^{\prime} \mathrm{N}$ & $29^{\circ} 11.32^{\prime} \mathrm{E}$ & $22.79 \pm 2.25$ & $7.40 \pm 1.08$ & $2.50 \pm 0.38$ & 1.94 & $0.78 \pm 0.13$ & $15.39 \pm 2.12$ \\
\hline \multicolumn{9}{|l|}{ Shelf edge } \\
\hline BS $97 / 5 / 24$ & $43^{\circ} 41.88^{\prime} \mathrm{N}$ & $30^{\circ} 03.52^{\prime} \mathrm{E}$ & $8.50 \pm 1.30$ & $0.72 \pm 0.12$ & $0.93 \pm 0.17$ & & $0.12 \pm 0.02$ & $7.78 \pm 1.06$ \\
\hline BS 95/8/22 & $43^{\circ} 41.88^{\prime} \mathrm{N}$ & $30^{\circ} 03.52^{\prime} \mathrm{E}$ & $15.68 \pm 3.05$ & $0.72 \pm 0.12$ & $1.72 \pm 0.45$ & & $0.12 \pm 0.02$ & $14.96 \pm 0.23$ \\
\hline BS 95/8/9 & $44^{\circ} 00.38^{\prime} \mathrm{N}$ & $30^{\circ} 29.09^{\prime} \mathrm{E}$ & $9.99 \pm 2.8$ & $0.72 \pm 0.12$ & $1.10 \pm 0.42$ & & $0.12 \pm 0.02$ & $9.27 \pm 2.16$ \\
\hline
\end{tabular}

This delay in the reversal of the shelf circulation induced by the severe meteorological conditions in early April led to a modification of the spatial phytoplankton distribution compared to the mean climatological pattern (Fig. 8a,b). During the second half of April 1997, the highest phytoplankton biomasses were confined around the Danube's mouth and the northern and eastern extension of the bloom was delayed in agreement with the EROS 21 observations and satellite images (Cipollini et al. 1999). Consequently, in early May, model results show that the highest flux of detrital matter occurred at the Danube's mouth and south of it (Fig. 9a). This pattern differs from the mean climatological pattern presented in Fig. 9b.

During the second half of April and in early May ('early spring conditions'), more stable and weaker winds prevailed which were roughly comparable to the climatological mean winds in May. The model simulates a reversal of the flow and an anticyclonic gyre is generated at the Danube's mouth (Fig. 7c). As a result, the Danube's waters were first transported towards the north and eastern part of the shelf before being transported towards the south. The Danube plume was clearly visible, progressively extending to the northeastern part of the shelf (Fig. 7d). During this calm period, a passive tracer released at the Danube's mouth reached isohaline 17 in about $7 \mathrm{~d}$. The phytoplankton populations were progressively transported to the north and eastern part of the shelf (Fig. 8c) and their distribution was quite similar to the mean climatological pattern (Fig. 8d).

Different auto- and heterotrophic microbiological transformations of nutrients were evidenced during the progressive mixing of Danube fresh waters with marine waters. These transformations are essentially driven by growth and mortality processes of fresh water microorganisms (Bouvier 1998). The intensity of such processes is conditioned by the hydrodynamics of the Danube and Black Sea mixing, and in particular, by the residence time of the estuarine water, and has strong consequences for the N:P:Si nutrient balance available for coastal Black Sea phytoplankton (Ragueneau et al. 2002). Also, the difference of residence time of estuarine water in mid-April and early May was found to be an important factor controlling the capacities of fresh water populations discharged by the Danube to develop biomass during these 2 periods of contrasting meteorological conditions. In the first case, they rapidly met a strong salinity shock and did not have time to adapt and to grow in spite of optimal light and nutrients conditions as confirmed by EROS21 measurements (Bouvier 1998). The measured doubling time of these species was longer than the water residence time. In spring conditions, the doubling time of freshwater species was comparable to the residence time of the estuarine water and they had time to reach an important biomass between salinity 10 and 17 

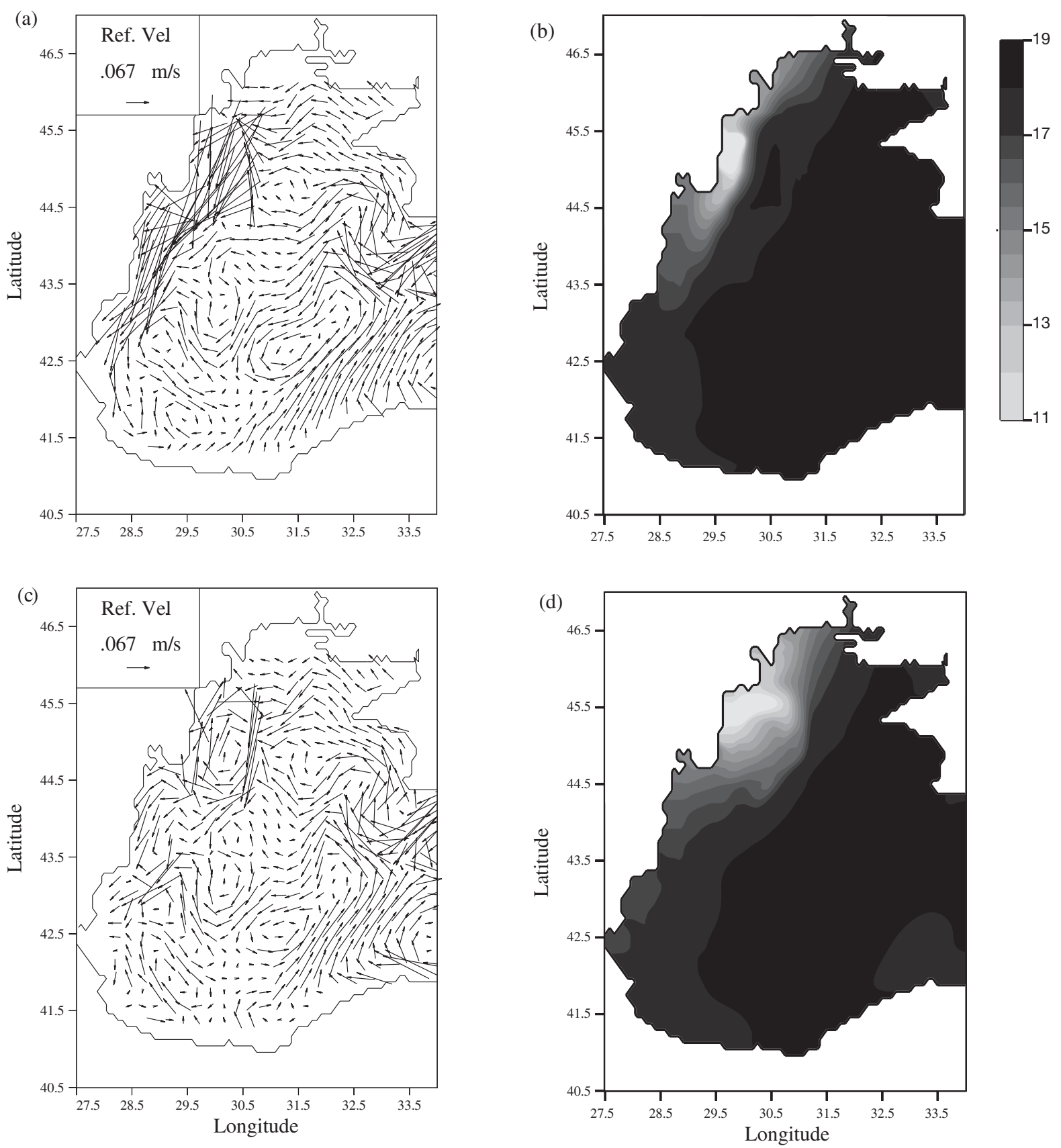

Fig. 7. Sea surface distribution of the currents $(a, c)$ and salinity field $(b, d)$. $(a, b)$ Mean values computed by the hydrodynamic model for the period of strong winds (i.e. before April 20), (c,d) mean values computed by the hydrodynamic model for the period of weak winds (i.e. after April 20). The comparison of $a, b$ and c,d clearly shows the extension of the fresh Danube's waters towards the northeastern part of the shelf after April 20 when weaker winds prevailed

as revealed by in situ observations (Bouvier 1998). Also, conservative and non-conservative trends in inorganic nutrients concentrations were observed in winter and spring conditions, respectively. This allows us to discriminate between 2 spatio-temporal distributions of the microbial network components with a higher development of the microbial network in spring conditions.

\section{Benthic fluxes}

The modeled phytoplankton distribution in April 1997 (Fig. 8a) indicates that the highest productivity waters were at the Danube's mouth and farther south at the Danube Prodelta, while very low phytoplankton concentration was simulated for the offshore shelf. The delay in the appearance of the anticyclonic gyre 

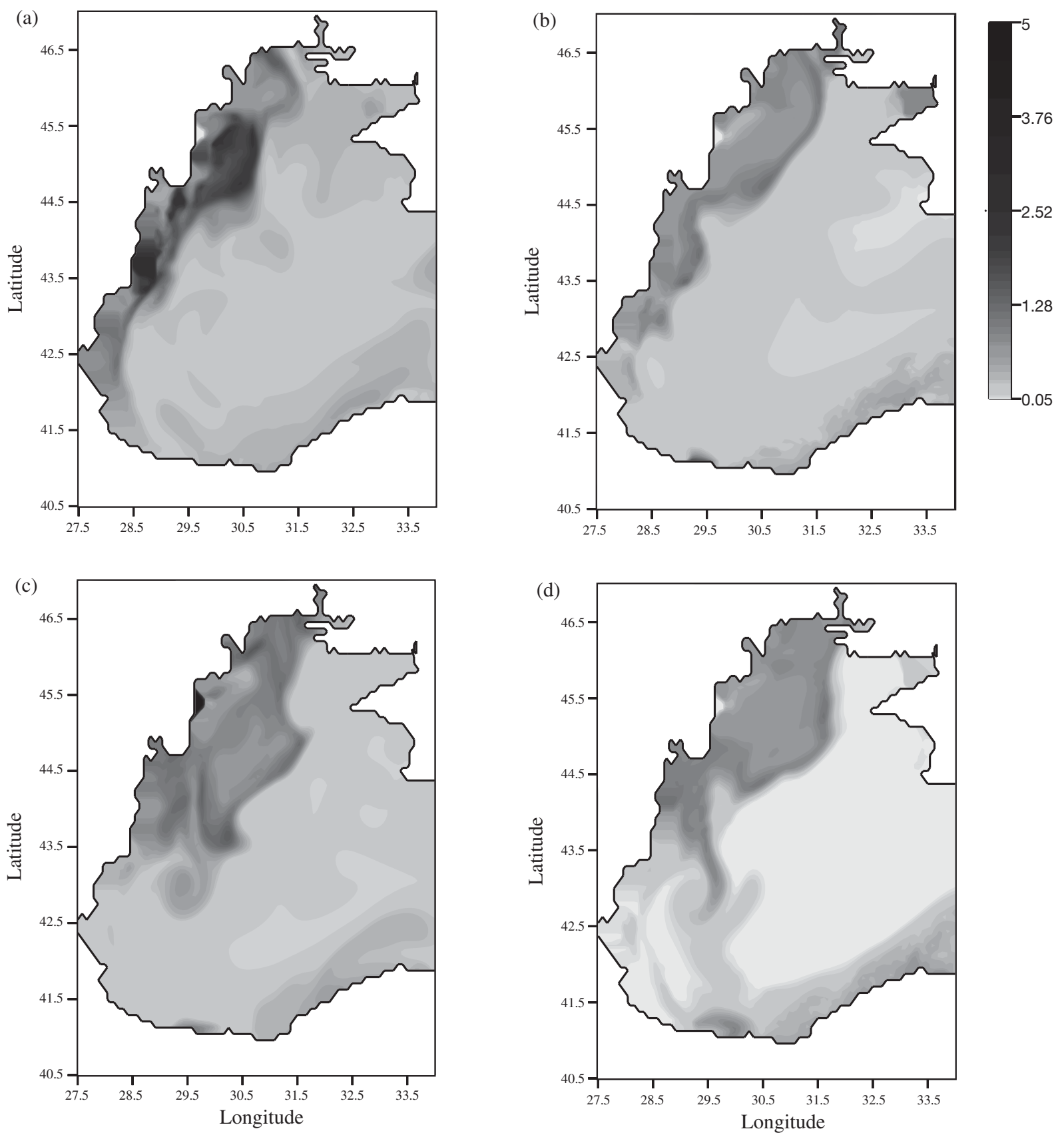

Fig. 8. Phytoplankton distribution at $10 \mathrm{~m}$ simulated by the model (in mmol $\mathrm{N} \mathrm{m}^{-3}$ ) (a) on April 25, 1997, (b) mean climatological pattern at the end of April, (c) on May 21, 1997, (d) mean climatological pattern at the end of May

in spring 1997, due to the unusual meteorological conditions, limited the northern and eastern extension of the high productivity waters. As a result, the highest flux of organic matter to the sediment could be expected at the Danube's mouth and south of it, whereas the flux of detrital matter to the sediments decreased in the northern and eastern part of the shelf (Fig. 9a), compared to the mean climatological situation (Fig. 9a,b).
The oxygen consumption in the flux chamber (Fig. 10) and SCOC rates (Wijsman et al. 1999) were higher at the Danube's mouth with 22.6 and $37.9 \mathrm{mmol}$ $\mathrm{O}_{2} \mathrm{~m}^{-2} \mathrm{~d}^{-1}$ (remineralization rates of about $3.54 \mathrm{mmol}$ $\mathrm{N} \mathrm{m}^{-2} \mathrm{~d}^{-1}$ ), respectively, than at the Dniestr mouth with 19.6 and $26.3 \mathrm{mmol} \mathrm{O}_{2} \mathrm{~m}^{-2} \mathrm{~d}^{-1}$ (remineralization rates of about $2.46 \mathrm{mmol} \mathrm{N} \mathrm{m}^{-2} \mathrm{~d}^{-1}$ ), respectively. In the Prodelta area, oxygen consumption and SCOC rates were similar with a value of $\sim 11.6 \mathrm{mmol} \mathrm{O}_{2} \mathrm{~m}^{-2} \mathrm{~d}^{-1}$ 

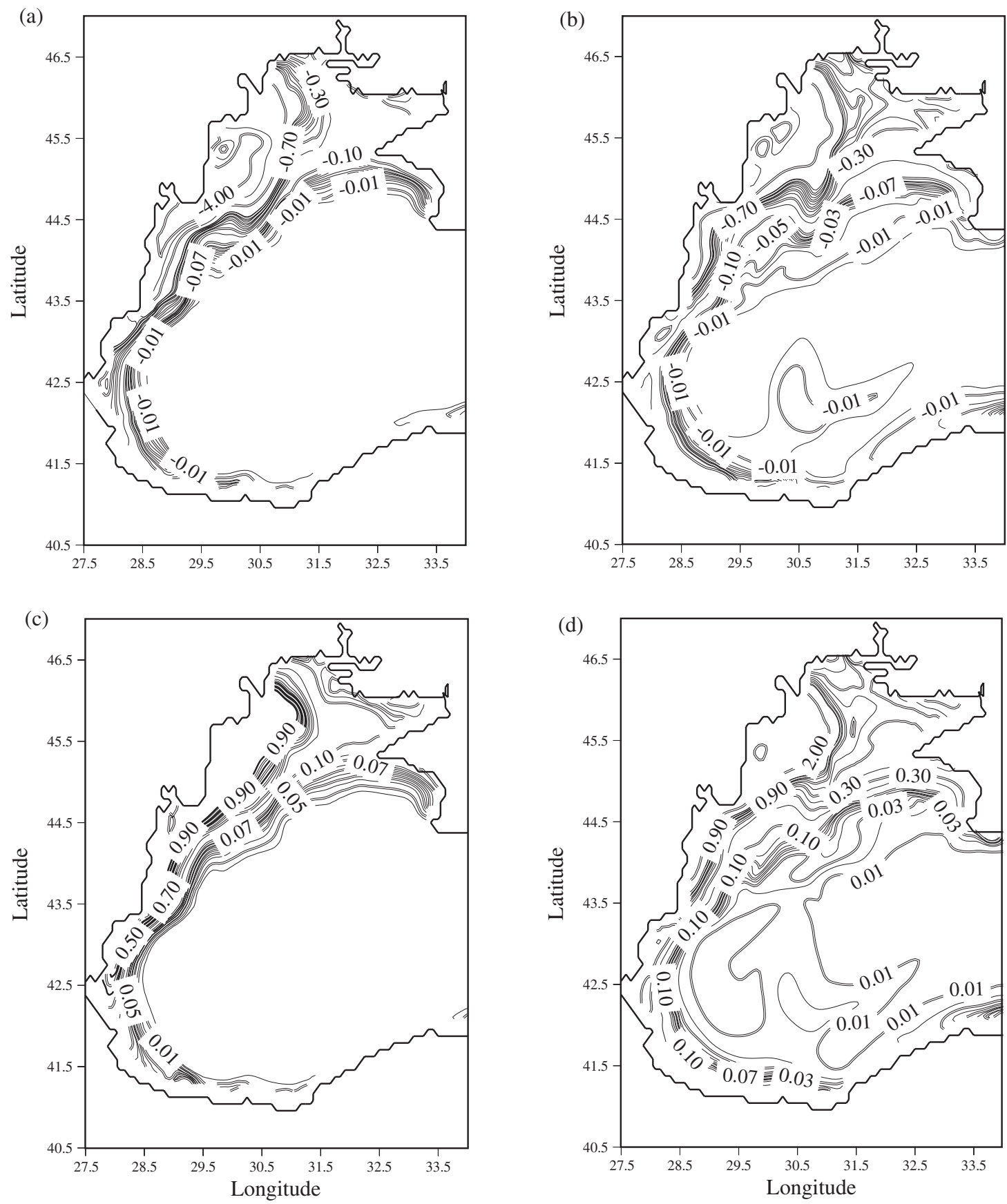

Fig. 9. Model estimated PON flux to the sediments $(\mathrm{a}, \mathrm{b})$ and ammonia outflux from the sediment $(\mathrm{c}, \mathrm{d})$ (in $\left.\mathrm{mmol} \mathrm{N} \mathrm{m}^{-2} \mathrm{~d}^{-1}\right)$ in $(a, c)$ early May 1997, (b,d) in May of a climatological year (negative values represent fluxes to the bottom)

(remineralization rates of $1.08 \mathrm{mmol} \mathrm{N} \mathrm{m}^{-2} \mathrm{~d}^{-1}$ ). Model results simulate nitrogen fluxes of about $4 \mathrm{mmol} \mathrm{N} \mathrm{m}^{-2}$ $\mathrm{d}^{-1}$ at the Danube mouth, $3 \mathrm{mmol} \mathrm{N} \mathrm{m}^{-2} \mathrm{~d}^{-1}$ in the Danube Prodelta area and between 0.2 and $2.7 \mathrm{mmol}$ $\mathrm{N} \mathrm{m}^{-2} \mathrm{~d}^{-1}$ on the northern shelf. In the offshore shelf waters, values varying between 0.05 and $0.56 \mathrm{mmol} \mathrm{N}$ $\mathrm{m}^{-2} \mathrm{~d}^{-1}$ were simulated.

In situ measurements (Fig. 11), in agreement with model results (Fig. 9c), show that the benthic nutrient regeneration was much higher nearshore than offshore, in early May 1997. During this period, the nitrogen benthic outfluxes were higher at the Danube's mouth $\left(1.5 \mathrm{mmol} \mathrm{NH}_{4}{ }^{+} \mathrm{m}^{-2} \mathrm{~d}^{-1},-0.1 \mathrm{mmol} \mathrm{NO}{ }_{3}^{-} \mathrm{m}^{-2}\right.$ $\left.\mathrm{d}^{-1}\right)$ and south of it at the Danube Prodelta $(1.7 \mathrm{mmol}$ $\mathrm{NH}_{4}{ }^{+} \mathrm{m}^{-2} \mathrm{~d}^{-1},-0.2 \mathrm{mmol} \mathrm{NO}{ }_{3}^{-} \mathrm{m}^{-2} \mathrm{~d}^{-1}$ ), than in the north at the Dniestr mouth $\left(1.2 \mathrm{mmol} \mathrm{NH}_{4}^{+} \mathrm{m}^{-2} \mathrm{~d}^{-1}\right.$, $0.16 \mathrm{mmol} \mathrm{NO}_{3}^{-} \mathrm{m}^{-2} \mathrm{~d}^{-1}$ ). Although the oxygen consumption was lower at the Danube Prodelta due to 
low bottom water oxygen concentration, the highest $\mathrm{NH}_{4}{ }^{+}$flux and highest nitrate consumption indicate a higher decomposition rate of organic matter than at the Dniestr mouth. Looking at the silica flux (Fig. 11), which is not influenced by redox processes in the flux chamber and is an indicator for the decomposition of siliceous organisms, highest benthic flux was detected at the Prodelta $\left(2.69 \mathrm{mmol} \mathrm{m}^{-2} \mathrm{~d}^{-1}\right)$ and at the Dniestr mouth $\left(2.51 \mathrm{mmol} \mathrm{m}^{-2} \mathrm{~d}^{-1}\right)$. The silica flux was lower at the Danube's mouth (1.89 mmol m $\left.\mathrm{m}^{-2} \mathrm{~d}^{-1}\right)$.

On the offshore shelf, the ammonia flux $\left(0.16 \mathrm{mmol} \mathrm{m}^{-2} \mathrm{~d}^{-1}\right)$ as well as the oxygen consumption $\left(16 \mathrm{mmol} \mathrm{O}_{2} \mathrm{~m}^{-2}\right.$ $\mathrm{d}^{-1}$ ) were lower than nearshore. At the shelf edge, under the influence of the anoxic water body of the central basins, no oxygen consumption was detected. The very low ammonia flux (0.13 $\mathrm{mmol} \mathrm{m} \mathrm{m}^{-2} \mathrm{~d}^{-1}$ ), nitrate consumption $\left(0.18 \mathrm{mmol} \mathrm{m}^{-2} \mathrm{~d}^{-1}\right)$ and silica flux indicate low decomposition rates of organic matter.
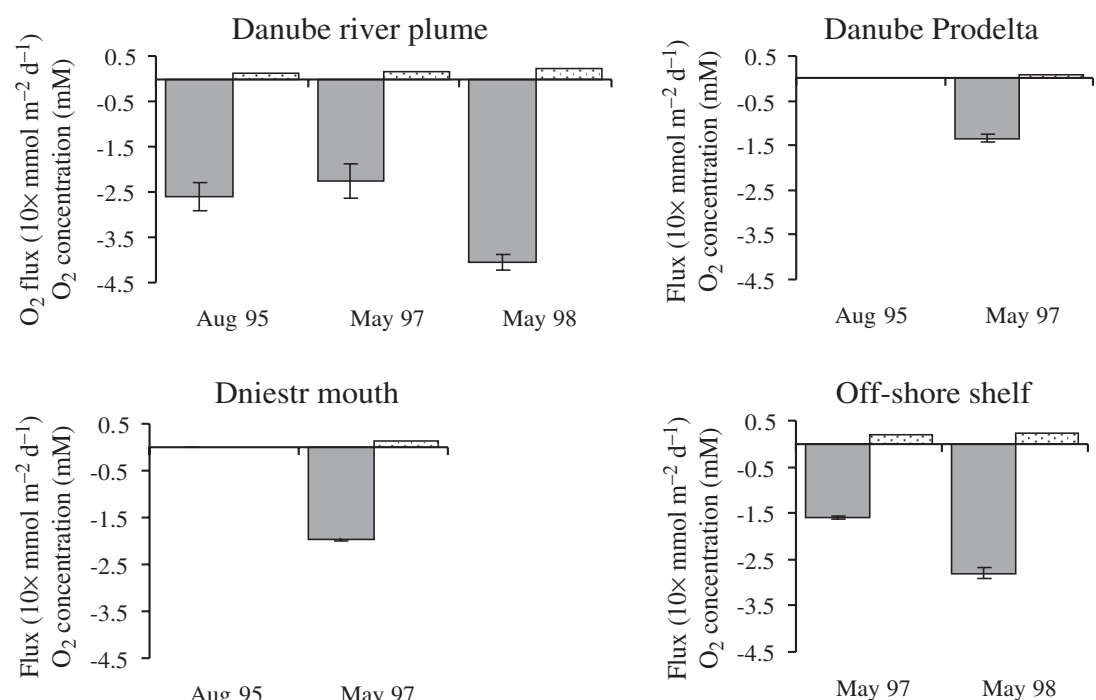

Fig. 10. Oxygen consumption measured with the flux chamber in $\mathrm{mmol} \mathrm{m}^{-2} \mathrm{~d}^{-1}$ (gray bars). Note that the flux was divided by 10 to fit the scale. Dotted bars represent the oxygen concentration in the bottom water in $\mathrm{mM}$, (a) within the Danube river plume, (b) at the Danube Prodelta, (c) at the Dniestr mouth, (d) on the offshore shelf and (e) at the shelf edge. In August 1995, at the Danube Prodelta and the Dniestr mouth, and in 1997 at Aug $95 \quad$ May 97 the shelf edge, the bottom water was anoxic

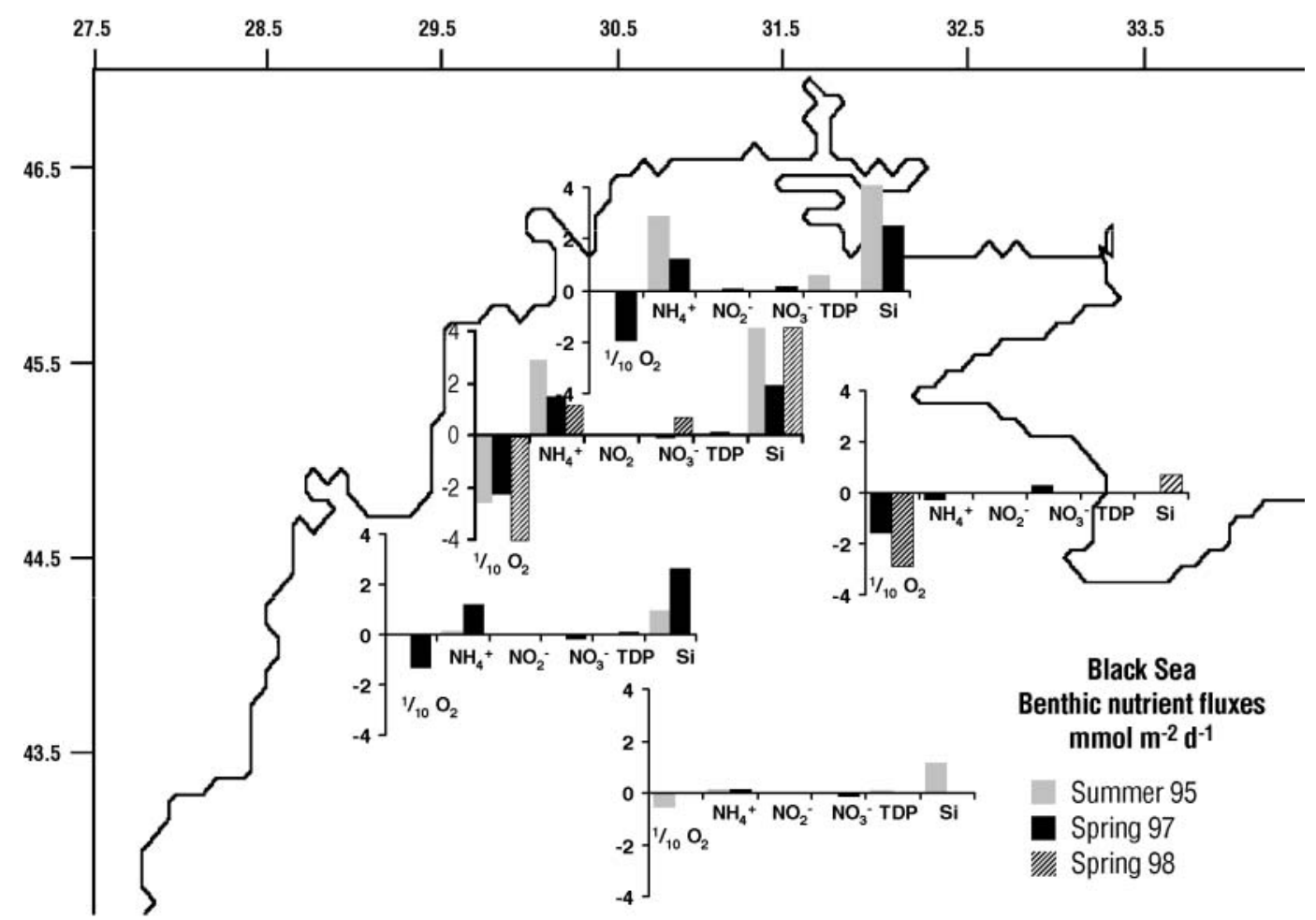

Fig. 11. Benthic fluxes of nutrients on the northwestern Black Sea shelf in August 1995, May 1997 and May 1998 in mmol m² $\mathrm{d}^{-1}$. The 1995 data is from Friedl et al. (1998) 

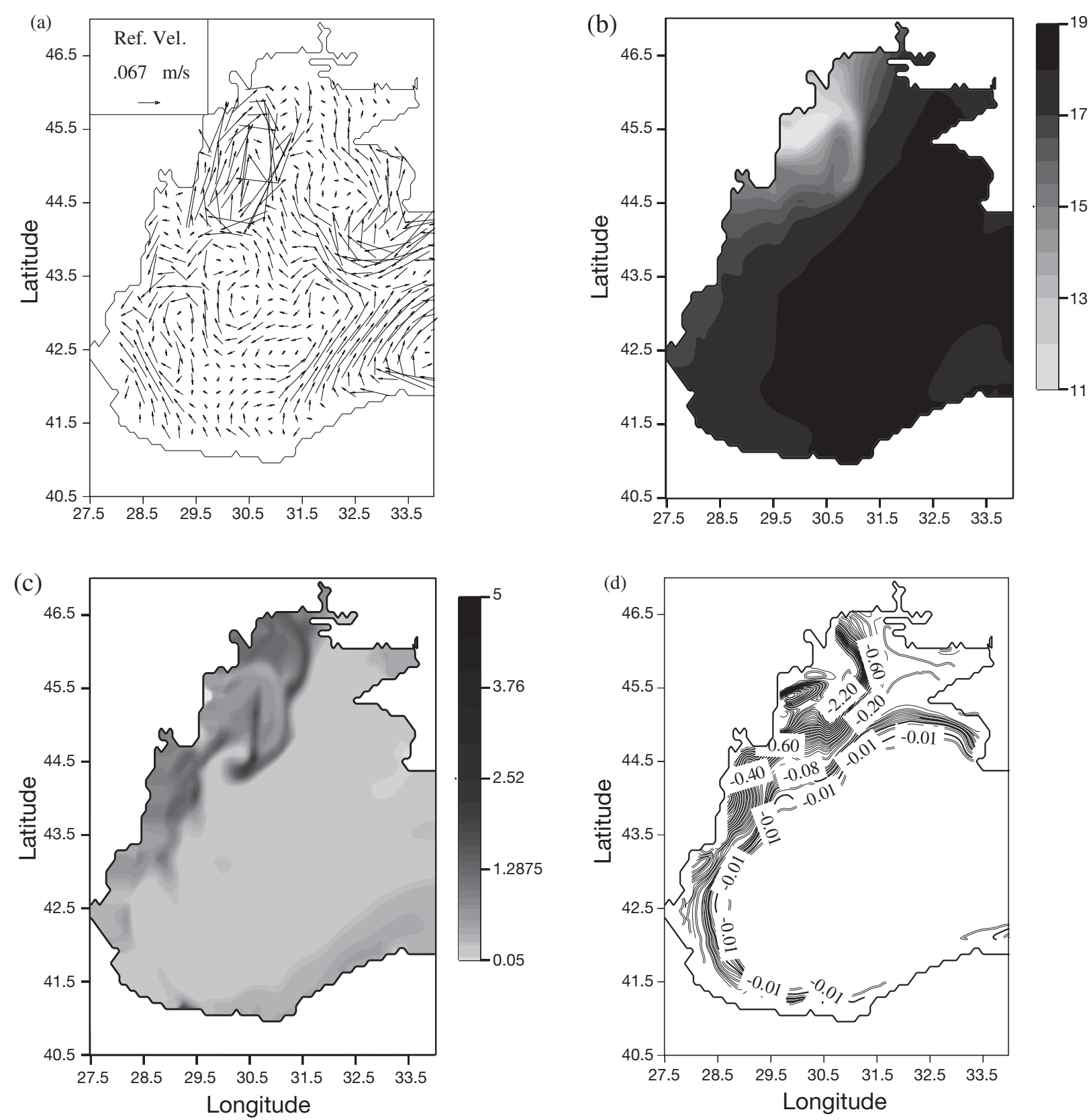

Fig. 12. Horizontal distribution simulated by the model in early May 1998 of (a) the currents and (b) the salinity field at the sea surface, (c) the phytoplankton distribution at $10 \mathrm{~m}$ (in mmol N m $\mathrm{m}^{-3}$ ) and (d) PON flux to the sediments (in $\mathrm{mmol} \mathrm{N} \mathrm{m}^{-2} \mathrm{~d}^{-1}$ ) (negative values represent fluxes to the bottom)

\section{Spring 98: model results and in situ measurements}

\section{Ecohydrodynamics}

In early May 1998, unusual strong southerly winds, 2 to 5 times more intense than the mean climatological winds, prevailed and generated an intense vertical mixing that reached the bottom in the shallowest areas. Also, these winds intensified the anticyclonic gyre formed off the Danube's mouth (Fig. 12a,b) and the highest phytoplankton biomasses were simulated in the northern part of the shelf and at the mid-shelf along the frontal interface (Fig. 12c).

\section{Benthic fluxes}

At the Danube's mouth, benthic oxygen consumption reached $40.4 \mathrm{mmol} \mathrm{m}^{-2} \mathrm{~d}^{-1}$, which suggests a high decomposition rate of organic matter (Fig. 10a). The 
Off-shore shelf May 98

$\mathrm{NO}_{3}{ }^{-}(\mathrm{mM})$

$\begin{array}{llllll}0.000 & 0.002 & 0.004 & 0.006 & 0.008 & 0.010\end{array}$

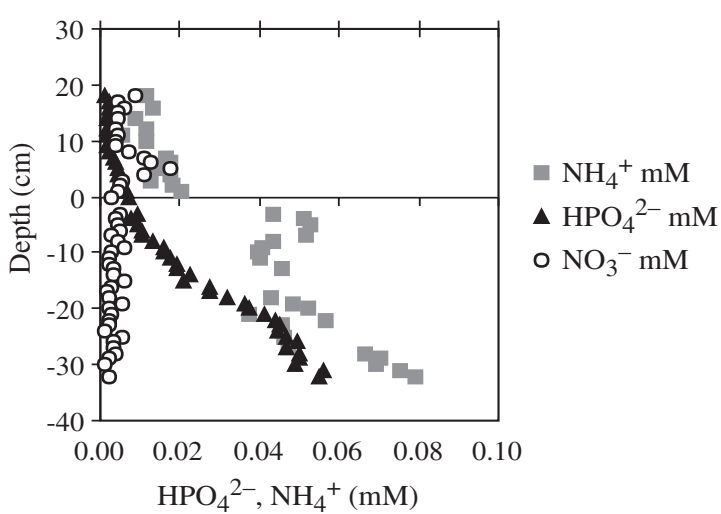

Dniestr Mouth

May 98

$\mathrm{NO}_{3}^{-}(\mathrm{mM})$

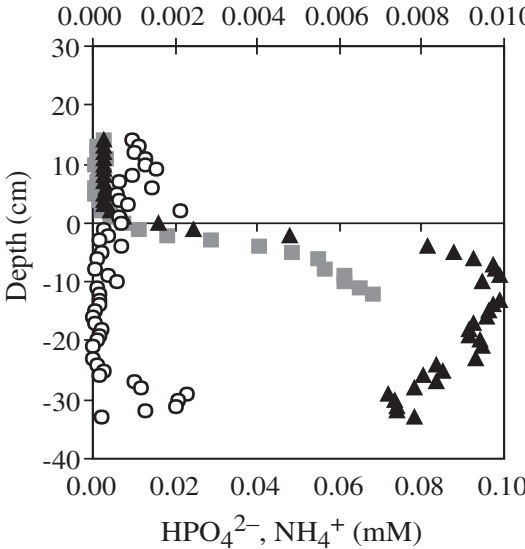

Fig. 13. Porewater profiles of nitrate, phosphate and ammonia in $\mathrm{mM}$ (a) on the offshore shelf and (b) at the Dniestr mouth in May 1998. The zero line marks the sediment-water interface benthic ammonia flux of $1.15 \mathrm{mmol} \mathrm{m}^{-2} \mathrm{~d}^{-1}$ was relatively low. Due to the high oxygen concentration, part of the ammonia in the chamber was oxidized to nitrate, resulting in a nitrate outflux of $0.66 \mathrm{mmol} \mathrm{m}^{-2} \mathrm{~d}^{-1}$. A high benthic silica flux of about $5 \mathrm{mmol} \mathrm{m}^{-2} \mathrm{~d}^{-1}$ (Fig. 11) indicates dissolution of siliceous organisms.

Since the flux chamber experiment on the Dniestr mouth failed, we relied on porewater profiles in this region. The porewater profiles of ammonia and phosphate show low concentration in the water above the sediment and a strong increase across the sediment-water interface and the uppermost $\mathrm{cm}$ of the sediment, indicating rapid remineralization of organic matter (Fig. 13b). In contrast, the porewater profile on the offshore shelf shows weaker concentration gradients of phosphate and ammonia (Fig. 13a). The intensity of benthic mineralization at the Dniestr mouth in comparison to the Danube's mouth was estimated from the ratio of the flux chamber phosphate flux at the Danube's mouth $\left(0.1 \mathrm{mmol} \mathrm{m}^{-2} \mathrm{~d}^{-1}\right)$ and the offshore shelf $\left(0.025 \mathrm{mmol} \mathrm{m}^{-2}\right.$ $\mathrm{d}^{-1}$ ) related to the porewater flux at the Dniestr mouth $\left(0.03 \mathrm{mmol} \mathrm{m}^{-2} \mathrm{~d}^{-1}\right)$ and the offshore shelf $(0.001 \mathrm{mmol}$ $\mathrm{m}^{-2} \mathrm{~d}^{-1}$ ). We deduce that the benthic phosphate flux at the Dniestr mouth was 7.5 times higher than at the Danube's mouth. Therefore, benthic remineralization may have been considerably higher in the northern part of the shelf in May 1998 than in spring 1997 as confirmed by model results (Fig. 12d).

\section{Summer 1995: model results and in situ measurements}

\section{Ecohydrodynamics}

In July 1995, northern winds dominated on the Black Sea's northwestern shelf with intensity similar to the climatological mean wind stress. During August 1995, the weather was calm and relatively constant. The model shows that the phytoplankton bloom extends on the whole shelf and progressively reaches the shelf break and the western part of the central basin (Fig. 14a).

\section{Benthic fluxes}

Fig. 14d shows the spatial distribution of EROS-21 SCOC rates on the Black Sea continental shelf published in Wijsman et al. (1999). This map can be compared with Fig. 14b showing model results for the same period. Fig. 14d shows that, in the shallow Black Sea's continental shelf, the SCOC ranged from 2 to $52 \mathrm{mmol} \mathrm{O}_{2} \mathrm{~m}^{-2} \mathrm{~d}^{-1}$ and the benthic community is likely to be inhibited by the oxygen conditions in the sediments resulting from the high carbon input rather than by the availability of organic matter to be remineralized (Wijsman et al. 1999).

EROS-21 observations as well as model results show that the highest fluxes were measured in the Danube Delta Front and also in the northern part of the shelf, where high primary productivity values were observed sustained by the Danube's discharges transported northward by the anticyclonic current of the shelf (Fig. 14a). Conversely, the southern part of the shelf was characterized by low sedimentation rates and low rates of benthic mineralization. Indeed, assuming a respiration coefficient of 0.85 (Hargrave 1973) and a $\mathrm{C}: \mathrm{N}$ ratio of 9.1 , the measured $\mathrm{SCOC}$ rates give nitrogen fluxes to the sediments ranging between 0.19 and $0.57 \mathrm{mmol} \mathrm{N} \mathrm{m}^{-2} \mathrm{~d}^{-1}$ at the shelf edge (SCOC rates of 2 to $6.1 \mathrm{mmol} \mathrm{O}_{2} \mathrm{~m}^{-2} \mathrm{~d}^{-1}$ ) and 2.34 and $4.86 \mathrm{mmol} \mathrm{N} \mathrm{m}^{-2}$ $\mathrm{d}^{-1}$ in the Danube discharge area with 2.33 to $2.8 \mathrm{mmol}$ 

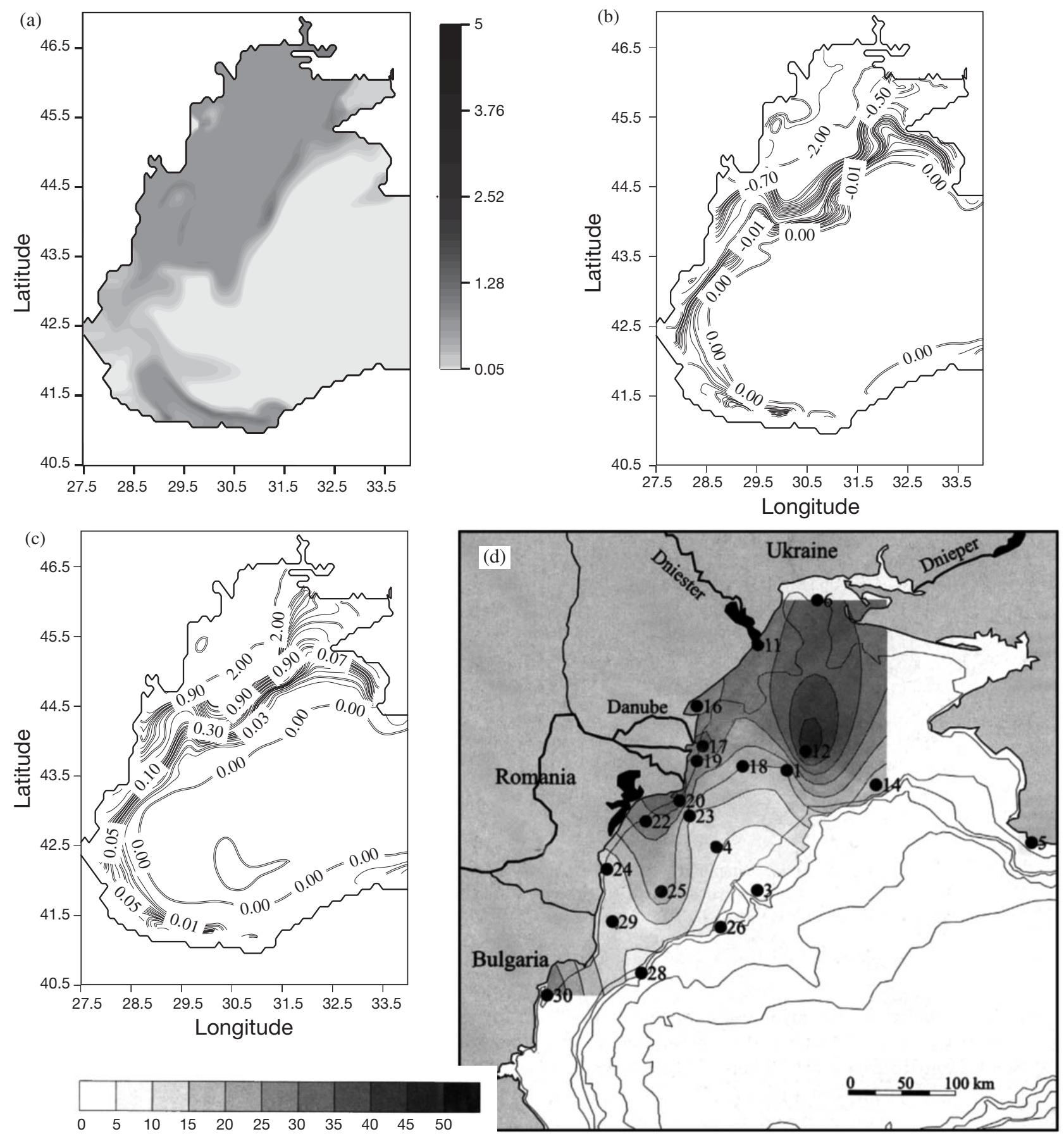

Fig. 14. (a) Phytoplankton distribution at $10 \mathrm{~m}$ (in mmol $\mathrm{N} \mathrm{m}^{-3}$ ), (b) PON flux to the sediment (in $\mathrm{mmol} \mathrm{N} \mathrm{m}^{-2} \mathrm{~d}^{-1}$ ), (c) ammonia outflux (in mmol N m $\mathrm{m}^{-1}$ ), all simulated by the model in August 1995, (d) spatial distribution of sediment community oxygen consumption (SCOC) $\left(\mathrm{mmol} \mathrm{O}_{2} \mathrm{~m}^{-2} \mathrm{~d}^{-1}\right)$ on the continental shelf measured using deck incubation. (•) Stations where SCOC was measured; (d) was reproduced from Wijsman et al. 1999

$\mathrm{N} \mathrm{m}^{-2} \mathrm{~d}^{-1}$ in the Danube Prodelta and $3 \mathrm{mmol} \mathrm{N} \mathrm{m}^{-2} \mathrm{~d}^{-1}$ at the Danube's mouth (SCOC rates of 25 to $52 \mathrm{mmol}$ $\mathrm{O}_{2} \mathrm{~m}^{-2} \mathrm{~d}^{-1}$, average $32.1 \mathrm{mmol} \mathrm{O}_{2} \mathrm{~m}^{-2} \mathrm{~d}^{-1}$ ) and in the northern shelf (2.33 to $3.27 \mathrm{mmol} \mathrm{N} \mathrm{m}{ }^{-2} \mathrm{~d}^{-1}$ at the Dniestr mouth) (shelf average $1.96 \mathrm{mmol} \mathrm{N} \mathrm{m} \mathrm{N}^{-2} \mathrm{~d}^{-1}$ ). Model results show values of 2.2 to $3.7 \mathrm{mmol} \mathrm{N} \mathrm{m}^{-2} \mathrm{~d}^{-1}$ in the Dniestr mouth area, 2 to $3 \mathrm{mmol} \mathrm{N} \mathrm{m}{ }^{-2} \mathrm{~d}^{-1}$ in the Danube mouth area and 0.5 to $2 \mathrm{mmol} \mathrm{N} \mathrm{m}{ }^{-2} \mathrm{~d}^{-1}$ at the Danube Prodelta. At the offshore shelf, simulated values are of 0.2 to $1.8 \mathrm{mmol} \mathrm{N} \mathrm{m} \mathrm{N}^{-2} \mathrm{~d}^{-1}$.

At the nearshore station, Danube Prodelta, the bottom water was already depleted in oxygen due to de- 
composition of organic matter. In contrast, at the shelf edge, the bottom water was almost oxygen free due to the shoaling of the permanent anoxic water body. Organic matter on the sediment was decomposed by anaerobic processes. The SCOC rates measured by Wijsman et al. (1999) and represented in Fig. 14d are in agreement with measured oxygen consumption values presented in Fig. 10a (for all oxygen consumption rates, we have to consider the associated $21 \%$ of the consumption by macrobenthos). Indeed, at the Danube's mouth, oxygen consumption by the sediment was $25.9 \mathrm{mmol} \mathrm{O}_{2} \mathrm{~m}^{-2} \mathrm{~d}^{-1}$ (Fig. 10a) which was slightly lower than the SCOC rates of $32.1 \mathrm{mmol} \mathrm{O}_{2} \mathrm{~m}^{-2} \mathrm{~d}^{-1}$ measured by Wijsman et al. (1999) at the same time and location. At the Dniestr mouth, Friedl et al. (1998) did not record oxygen due to drift of the sensor, presumably caused by outflux of $\mathrm{H}_{2} \mathrm{~S}$. The $\mathrm{H}_{2} \mathrm{~S}$ flux of $0.3 \mathrm{mmol} \mathrm{m}^{-2} \mathrm{~d}^{-1}$ suggests that a considerable amount of organic matter might have been decomposed by anaerobic respiration. In contrast, Wijsman et al. (1999) reported SCOC rates of 30 to

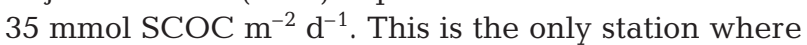
in situ oxygen measurements and deck incubation provide contradicting results.

In situ measurements (Fig. 11), in agreement with model results (Fig. 14c) show that the nearshore ammonia flux from the sediment ranged from $0.1 \mathrm{mmol}$ $\mathrm{m}^{-2} \mathrm{~d}^{-1}$ on the Prodelta to $4.5 \mathrm{mmol} \mathrm{m}^{-2} \mathrm{~d}^{-1}$ at the Dniestr mouth. Offshore, the ammonia flux reached only $0.16 \mathrm{mmol} \mathrm{m} \mathrm{m}^{-2} \mathrm{~d}^{-1}$. The high ammonia fluxes at the Danube's mouth $\left(2.9 \mathrm{mmol} \mathrm{m}^{-2} \mathrm{~d}^{-1}\right)$ and at the Dniestr mouth $\left(4.5 \mathrm{mmol} \mathrm{m}^{-2} \mathrm{~d}^{-1}\right)$ as well as the high silica flux (6.3 mmol m $\mathrm{m}^{-2} \mathrm{~d}^{-1}$ at both stations) suggest high decomposition rates of organic matter in that area as predicted by the model (Fig. 14a,b).

\section{DISCUSSION}

\section{Spatial and temporal variability}

Modeling experiments and in situ observations show spatial and temporal variability in benthic processes in the northwestern Black Sea in summer 1995, spring 1997 and spring 1998.

\section{Spatial variability}

In agreement with model results, in situ observations have shown that the highest consumption of oxygen was measured in the Danube river plume and in the northern part of the shelf, while the eastern part of the shelf was characterized by low sedimentation rates and low rates of benthic mineralization. Nearshore, the intense benthic recycling and high benthic nutrient fluxes are triggered by high productivity and high sedimentation caused by river input of organic matter and nutrients. Offshore, benthic nutrient regeneration is low due to low biologic productivity. This region includes the eastern part of the shelf and the shelf break, which receive nutrient-rich water only in summer when a strong anticyclonic current spreads river plume water over the whole shelf. The simulated horizontal distribution of the mean annual flux of detrital organic matter that reaches the shelf sediments show the presence of a region of high sedimentation, with a flux higher than $1 \mathrm{mmol} \mathrm{N} \mathrm{m}{ }^{-2} \mathrm{~d}^{-1}$, nearshore and in the northern part of the shelf covering about $15 \%$ of the shelf area (about $7650 \mathrm{~km}^{2}$ ), while the low fluxes area covers about $85 \%$ (about $42350 \mathrm{~km}^{2}$ ) of the shelf area.

The measured oxygen consumptions on the northwestern shelf Black Sea are in the same range as other measurements of $\mathrm{O}_{2}$ uptake by the sediments in different estuarine, coastal and shelf areas. In the Northern Adriatic for example, 6.4 to $30 \mathrm{mmol} \mathrm{O}_{2} \mathrm{~m}^{-2} \mathrm{~d}^{-1}$ were measured in spring and summer (Epping \& Helder 1997), on the Washington Shelf, $5.7 \mathrm{mmol} \mathrm{O}_{2} \mathrm{~m}^{-2} \mathrm{~d}^{-1}$ were reported by Archer \& Devol (1992), on the Eastern N-Pacific Shelf, Devol \& Christensen (1993) measured $18.2 \mathrm{mmol} \mathrm{O}_{2} \mathrm{~m}^{-2} \mathrm{~d}^{-1}$ and in the Westerschelde, 95 $\mathrm{mmol} \mathrm{O}_{2} \mathrm{~m}^{-2} \mathrm{~d}^{-1}$ were measured by Dauwe et al. (2001). Although the oxygen consumption does not seem to reveal an extremely eutrophicated situation on the northwestern Black Sea shelf, sporadic occurrence of hypoxia suggests that the ecosystem of the shelf is in a critical state between recovery and deterioration.

The spatial distribution of the benthic inorganic nitrogen outfluxes followed the distribution of the carbon flux to the sediment. The highest ammonia benthic outfluxes, ranging from 0.08 to $4.45 \mathrm{mmol} \mathrm{m}^{-2}$ $\mathrm{d}^{-1}$ (average $1.47 \mathrm{mmol} \mathrm{m}^{-2} \mathrm{~d}^{-1}$ ), were observed in the Danube discharge area with the highest values in the northern part of the shelf, while at the shelf edge and on the offshore shelf, the benthic ammonia outfluxes were lower (from 0 to $0.16 \mathrm{mmol} \mathrm{m}^{-2} \mathrm{~d}^{-1}$, average 0.074). Nearshore, benthic fluxes of ammonia were about 1 order of magnitude higher (1.2 to $4.5 \mathrm{mmol}$ $\left.\mathrm{m}^{-2} \mathrm{~d}^{-1}\right)$ than on the offshore shelf $\left(<0.16 \mathrm{mmol} \mathrm{m}^{-2} \mathrm{~d}^{-1}\right)$.

\section{Temporal variability}

The seasonal and inter-annual variability of the benthic nutrient recycling is essentially driven by the seasonal variability of the spatial phytoplankton pattern, the surface circulation and the vertical mixing intensity which enriches the water column in oxygen. The variability of the northwestern shelf ecohydrodynamics depends on various combinations of river outflow conditions (mainly the annual cycle of the Danube's 
outflow, the amount and relative composition of the inorganic nutrients discharged), wind forcing and Rim current structure (e.g. Nezlin et al. 1999, Oguz et al. 2002). Seasonal and inter-annual variability were observed both in the nearshore high flux region and in the offshore low flux region.

Seasonal variability. Comparison of the Danube River plume's position in spring and summer in the climatological mean pattern (Fig. 3b,d) shows that the flux of detrital organic matter to the sediment and the resulting benthic nutrient regeneration might be higher in spring after the peak of primary productivity in the nearshore part of the shelf. In summer, low salinity waters enriched in nutrients from the river are spread more broadly over the shelf. Therefore, in summer, higher particle and benthic fluxes than in spring can be expected in the offshore part of the shelf and at the shelf break.

This was confirmed by EROS-21 observations performed in August 1995 and May 1997. Indeed, the measured oxygen uptake by the sediment and benthic ammonia outfluxes were higher in summer 1995 on the northern and eastern parts of the shelf and at the shelf break. On the other hand, in spring 1997, the highest fluxes were observed south of the Danube's mouth, in agreement with the distribution of the primary production spatial pattern at these 2 periods (Figs. 8a,c \& 14a).
Moreover, it should be noted that the higher temperatures in August may enhance benthic activities and partly compensate for the lower carbon flux in some regions at this period (Wijsman et al. 1999). Also, in some areas such as the Danube's mouth, although we had comparable oxygen consumption, the benthic outfluxes of inorganic nutrients (e.g. silicate and ammonia) was about 2 times higher.

Inter-annual variability. The inter-annual variability of the benthic nutrient regeneration observed during the 2 expeditions in spring 1997 and 1998 was mainly caused by deviations in the meteorological conditions from the climatological mean pattern. In contrast to the situation in spring 1997 when the anticyclonic gyre was delayed, in spring 1998 the unusual strong southerly winds intensified the anticyclonic gyre that transported the Danube plume waters to the north. The increased phytoplankton development due to the nutrient-enriched waters in that area resulted in higher flux of organic matter to the sediments, in agreement with field observations and model results (Figs. $10 \& 12 \mathrm{~d}$ ). Consequently, the benthic nutrient regeneration was intensified. In addition, the strong winds generated intense vertical mixing that ventilated the water column leading to higher bottom water oxygen concentrations in spring 1998 (0.23 mM) than in spring 1997 (0.18 mM), and thus, to a higher flux of (a)

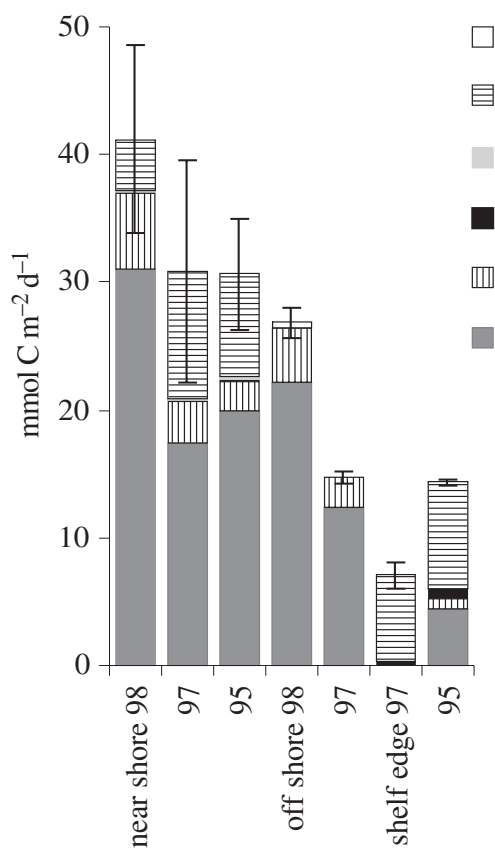

methanogenesis

sulfate reduction

iron reduction

manganese reduction

III nitrate reduction

aerobic respiration (b)

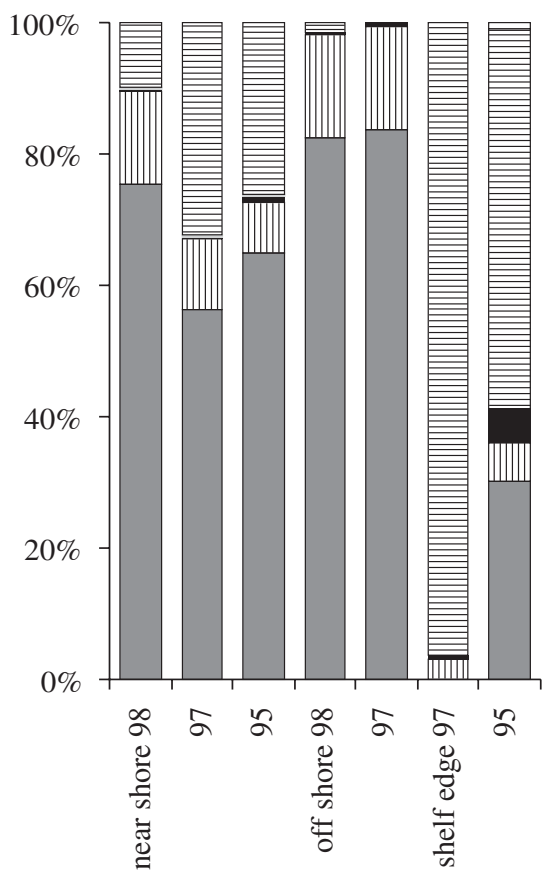

Fig. 15. Decomposition of organic matter in $\mathrm{mmol} \mathrm{m}^{-2} \mathrm{~d}^{-1}$ by aerobic respiration, nitrate reduction, manganese, iron and sulfate reduction and methanogenesis. Decomposition rates were calculated from benthic fluxes according to diagenetic equations (Aller 1982). Error estimates refer to the total decomposition rate and were calculated by error propagation. Sulfate reduction and methanogenesis data from N. Pimenov (pers. comm.). (a) Absolute and (b) relative contribution of the diagenetic pathways 
oxygen to the sediments. Due to the intensified aerobic decomposition of organic matter, the oxygen uptake by the sediment was higher in spring 1998 (29 and $40 \mathrm{mmol} \mathrm{m}^{-2} \mathrm{~d}^{-1}$ ) at the offshore shelf and at the Danube's mouth than in spring 1997 (16 and $23 \mathrm{mmol}$ $\left.\mathrm{m}^{-2} \mathrm{~d}^{-1}\right)$.

The oxygen consumption and the silica flux were higher in early May $1998\left(40 \mathrm{mmol} \mathrm{O} \mathrm{m}^{-2} \mathrm{~d}^{-1}, 5 \mathrm{mmol}\right.$ $\mathrm{SiO}_{4} \mathrm{~m}^{-2} \mathrm{~d}^{-1}$ ) than in May $1997\left(23 \mathrm{mmol} \mathrm{O}_{2} \mathrm{~m}^{-2} \mathrm{~d}^{-1}\right.$, $1.9 \mathrm{mmol} \mathrm{SiO}_{4} \mathrm{~m}^{-2} \mathrm{~d}^{-1}$ ) at the Danube Delta Front. Offshore, we found the same pattern, with higher fluxes in May $1998\left(29 \mathrm{mmol} \mathrm{O} \mathrm{m}^{-2} \mathrm{~d}^{-1}, 1.4 \mathrm{mmol}\right.$ $\mathrm{SiO}_{4} \mathrm{~m}^{-2} \mathrm{~d}^{-1}$ ) than in May 1997 (16 mmol O $\mathrm{m}^{-2} \mathrm{~d}^{-1}$, $0.35 \mathrm{mmol} \mathrm{SiO}_{4} \mathrm{~m}^{-2} \mathrm{~d}^{-1}$ ).

\section{Benthic mineralization pathways on the Black Sea shelf}

We assessed the importance of diagenetic pathways by calculating decomposition rates of organic matter according to the diagenetic reactions of Aller (1982). Accounting for the seasonal and inter-annual variability of benthic nutrient regeneration, the largest amount of organic matter was remineralized nearshore, in the region of high particle fluxes due to the input of organic matter and nutrients from the rivers Danube and Dniestr (Fig. 15a). On the offshore shelf, the total decomposition rate of organic matter was lower in all years and seasons sampled. The lowest decomposition rates were estimated for the shelf edge. In the nearshore high flux region, more than $55 \%$ and on the offshore low flux shelf more than $80 \%$ of the organic matter was decomposed by aerobic respiration, considering seasonal and inter-annual variability (Fig. 15b). For the winter season, we assume the decomposition rates to be lower on the whole shelf due to sloweddown microbial processes and lower biologic production. The aerobic decomposition pathway might be of more importance due to winter storm-induced mixing and less benthic oxygen demand. Some authors have claimed that aerobic respiration is faster and more efficient than anaerobic decomposition (Kristensen et al. 1995, Hulthe et al. 1998). Dauwe et al. (2001) confirmed that aerobic mineralization is faster, irrespective of the degree of lability of organic matter, especially at low mineralization rates. According to them, the effect of oxygen on mineralization also depends on the mineralization rate. For the offshore shelf, we have to consider that the aerobic rate of organic matter decomposition might have been lower than the measured oxygen consumption due to the activity of macrozoobenthos, as suggested by the low ammonia, nitrate and silica fluxes. In the high flux region, sulfate reduction was the most important anaerobic pathway, whereas denitrification was more important in the low flux region on the offshore shelf. Depending on the availability of nitrate, denitrifiers and sulfate reducers compete for substrate. At the shelf edge, under the influence of the anoxic water body, more than $60 \%$ of organic matter is remineralized by sulfate reduction. Only a few percent of organic matter was decomposed by methanogenesis. At high sulfate concentrations in marine waters, sulfate reducers outcompete methanogenic bacteria for substrate.

\section{Mass balance of POC and PON for the Black Sea shelf}

Quantification of POC and PON flux reaching sediments

The total annual carbon flux to the Black Sea's northwestern shelf sediments was estimated using model results and in situ observations. The model estimates the amount of organic matter remineralized in the sediments every year on the whole shelf during a climatological year to be $182 \times 10^{3} \mathrm{t} \mathrm{N}$. This amounts to $12 \%$ of the estimated phytoplankton nitrogen requirements per year (Gregoire \& Lacroix 2003). Using the C:N mass ratio of 7.8 for the rapidly sinking organic matter, the POC flux that reaches the sediments equals $1.4 \times 10^{6} \mathrm{t} \mathrm{C} \mathrm{yr}^{-1}$.

The POM flux to the sediment was derived from a mass balance of organic matter decomposition from measured SCOC, benthic nutrient regeneration and nutrient burial in the sediment. The mass balance was calculated for each sampled station (Table 3) and then averaged for the $7650 \mathrm{~km}^{2}$ high flux region nearshore and the $42350 \mathrm{~km}^{2}$ low flux region offshore (Fig. 16a). For the high flux region, the mass balance yields a POC flux reaching the sediments (gross sedimentation) of $1280 \times 10^{3} \pm 210 \times 10^{3} \mathrm{t} \mathrm{yr}^{-1}$ and a PON flux of $164 \times 10^{3} \pm 23 \times 10^{3} \mathrm{t} \mathrm{yr}^{-1}$. In the low flux region offshore (Fig. 16a), the particle flux to the sediments deduced from the mass balance

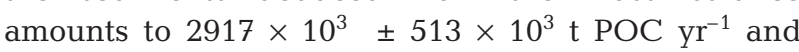
$374 \times 10^{3} \pm 5610^{3} \mathrm{t} \mathrm{PON} \mathrm{yr}^{-1}$. Therefore, the mass balance of benthic fluxes and burial in the sediment gives a POC flux to the sediments of 3.7 to $4.2 \times 10^{6} \mathrm{t}$ $\mathrm{C} \mathrm{yr}^{-1}$ for the whole shelf which is in agreement with the value of $3.7 \times 10^{6} \mathrm{t} \mathrm{C} \mathrm{yr}^{-1}$ derived from the SCOC rates measurements (Wijsman 2001). With this estimation, the fraction of the primary production deposited on the shelf is around $33 \%$, and is in agreement with the global estimation of 27 to $30 \%$ given by Wollast (1998) using in situ observations and semi-empirical equations.

Also, the model estimated carbon flux to the sediment of $1.4 \times 10^{6} \mathrm{t} \mathrm{C} \mathrm{yr}^{-1}$ is much lower than the estimate of 3.7 to $4.2 \times 10^{6} \mathrm{t} \mathrm{C} \mathrm{yr}^{-1}$ derived from in situ 

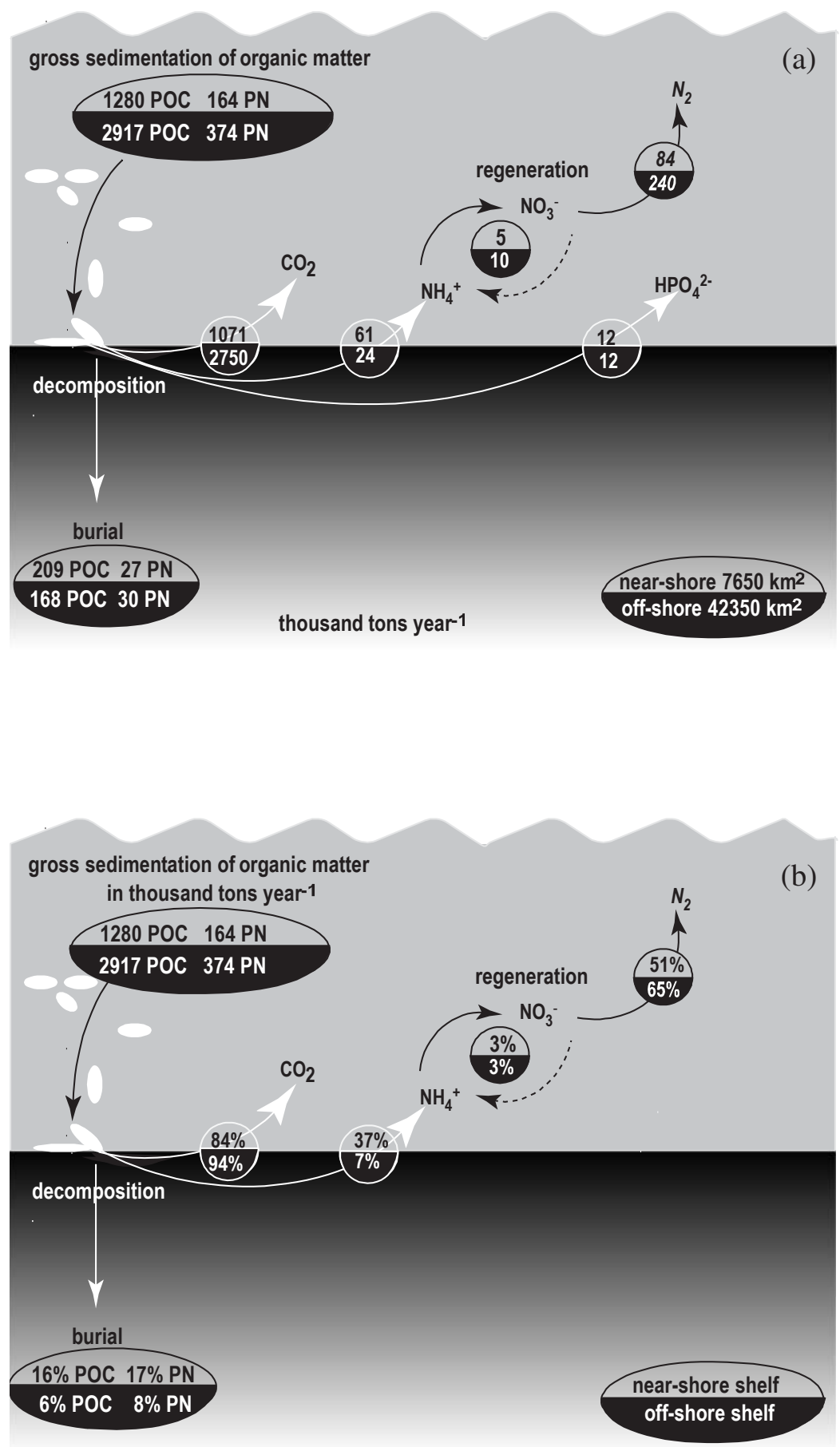

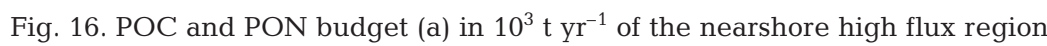
( $15 \%$ of the northwestern shelf) and the offshore low flux region (85\% of the northwestern shelf), derived from a mass balance of benthic mineralization from measured sediment community oxygen consumption and benthic fluxes and burial in the sediment and (b) percentages of burial and regeneration. POC and PON content of the sediment was taken from Reschke (1999). The percentage of burial, ammonia and nitrate release is much lower in the low flux region, which might be in part due to the overestimation of the particle flux to the sediment. The SD of the organic matter gross sedimentation and organic matter decomposition, calculated for the mean of the stations in the high and low flux regions account for 34 and $44 \%$, respectively observations performed during EROS21. However, it should be noted that these global fluxes derived from EROS-21 observations may have been overestimated because they are derived from measurements taken essentially in the most productive part of the Black Sea's northwestern shelf during August and May when mineralization rates are usually high. Moreover, more than $21 \%$ of the SCOC is consumed by the activity of benthic organisms (Wijsman et al. 1999). Also, the EROS-21-derived integrated values have to be considered as upper estimates. On the other hand, the coarse resolution of the shelf bathymetry used in the model (the water depth of the shelf is overestimated in the model, the lowest depth is $80 \mathrm{~m}$, while in reality, the mean shelf depth is about $50 \mathrm{~m}$ ) leads to an underestimation of the flux reaching the sediments. In the model, most of the organic matter is remineralized in the water column before reaching the bottom.

\section{Benthic inorganic nitrogen outfluxes}

In shallow waters, benthic nutrient recycling is an important factor in sustaining the high productivity in the system and affecting the chemical composition of the seawater. The model estimates the shelf-integrated annual ammonia benthic outflux for a climatological year to be $174 \times 10^{3} \mathrm{t}$. On the other hand, the extrapolation over the whole shelf and the year of the EROS21 benthic nitrogen outfluxes taken in summer 1995 and spring 1997 gives a rough estimate of the shelf summer and spring integrated nitrogen annual benthic outflux equivalent to $85 \times 10^{3} \mathrm{t}$ (ammonia-N outflux) and $100 \times 10^{3} \mathrm{t}$ of dissolved inorganic nitrogen (DIN) (for the nitrate and ammonia outflux). The high flux region contributes to $61 \times$ $10^{3} \mathrm{t} \mathrm{NH}_{4} \mathrm{yr}^{-1}$ and $5 \times 10^{3} \mathrm{t} \mathrm{NO}_{3} \mathrm{yr}^{-1}$. Approximately $84 \times 10^{3} \mathrm{t} \mathrm{N} \mathrm{yr}^{-1}$ is lost by denitrification. The low flux region offshore contributes $24 \times 10^{3} \mathrm{t} \mathrm{NH}_{4} \mathrm{yr}^{-1}$ and $10 \times 10^{3} \mathrm{t} \mathrm{NO}_{3} \mathrm{yr}^{-1}$. These last values are about 2 times lower than the 
model estimation although the shelf integrated PON flux to the sediments derived from EROS-21 observations is 3 times higher than model results. This could suggest that the shelf sediments act as an important sink for riverine inorganic nitrogen due to some benthic processes of nitrogen elimination such as denitrification and burial. These last processes are not represented in the presented model. The estimated denitrification from in situ measurements amounts to $240 \times 10^{3} \mathrm{t} \mathrm{N} \mathrm{yr}^{-1}$ (Fig. 16a). However, it should be noted that the inorganic nitrogen benthic outflux derived from EROS-21 may have been underestimated because, on the one hand, the ammonia benthic fluxes are difficult to measure due to the oxidation processes in the flux chamber and, on the other hand, in summer 1995, the benthic nitrate flux has not been measured. According to Wollast (1998), the recycling of nitrogen through the benthic processes produces both nitrate and ammonia in similar amounts.

Both model results and in situ observations show that benthic nutrient recycling is the dominant source for ammonia, representing 4 to 7 times the Danube ammonia inputs. However, ammonia fluxes from the sediments amounted to be $\sim 12$ to $25 \%$ of the Danube total inorganic nitrogen input (Fig. 6) and account for only 4.8 to $11.4 \%$ of the model estimated phytoplankton requirement. This last estimation is lower than the mean value of 26 to $101 \%$ given by Kristensen (1988) for the coastal zone.

The importance of benthic recycling can be assessed by calculating the hypothetical turnover time for inorganic nitrogen in the shelf. This means the time necessary to replace the nutrients standing stock by benthic supply only, disregarding external sources such as river, vertical/lateral advective inputs. The shelf inventory of inorganic nitrogen divided by the benthic flux yields the turnover time. The model gives a turnover time of $50 \mathrm{~d}$ which is in the lower range of the EROS-21 estimations of 25 to $255 \mathrm{~d}$ for respectively the northernmost station and the shelf edge based on direct measurements (Friedl et al. 1998).

In situ measurements have shown that the daily benthic DIN input in the high flux region nearshore amounts to $2 \%$ of the nearshore water column inventory and $8 \%$ of the daily Danube input.

For phosphorus, nearshore, the daily benthic phosphorus flux adds up to $3 \%$ of the nearshore water column inventory, while the daily total dissolved phosphorus input of the Danube amounts to $13 \%$ of the nearshore inventory. Since the river input is phosphate deficient, the benthic recycling of phosphate is an important factor sustaining high productivity in the coastal zone of the Black Sea. Offshore, the influence of the benthic nutrient flux on the water column inventory is minor.

\section{Denitrification}

Mass balance calculations of the nitrogen fluxes measured during EROS-21 indicate that denitrification may be an important remineralization pathway in summer, with denitrification rates in the range of 1 to $2 \mathrm{mmol} \mathrm{N} \mathrm{m}^{-2} \mathrm{~d}^{-1}$ (Friedrich et al. 2002). This is confirmed by the N:P ratios of measured benthic fluxes (1.8 to 7.4$)$ in summer which are far lower than the Redfield ratio (16) and the ratio of the Danube (25) (Friedl et al. 1998). In our estimate, $60 \%$ of the PON deposited on the sediment of the Black Sea's northwestern shelf is lost through denitrification (51 and $65 \%$ for respectively the high and low flux areas) (Fig. 16b). These last percentages are in the range of the values reported in the literature providing the Black Sea's northwestern shelf to be an efficient sink for riverine nitrogen trapping 40 to $54 \%$ of the river total inorganic nitrogen discharge and about $100 \%$ of the DIN discharge. However, it should be noted that denitrification rates in the Black Sea might have been overestimated since they were estimated for summer when benthic processes including denitrification are the most intense due to the high temperature (Fig. 10). Furthermore, $\mathrm{N}_{2}$ benthic fluxes deduced from diagenetic reactions may have been overestimated since part of the nitrogen from PON may have been converted to DON instead of a complete conversion to DIN as assumed in the diagenetic reactions. Based on measurements in 11 North American and European estuaries, Dettmann et al. (2001) modeled the percentage of total internal nitrogen loss attributable to denitrification to be 61 to $90 \%$. The authors further hypothesize a strong positive relationship of freshwater residence time in the estuary and the fraction of nitrogen supplied by the river that is denitrified. Earlier work provides lower denitrification values for world estuaries. Seitzinger (1988) reported denitrification is responsible for removing 20 to $50 \%$ of the nitrogen input to estuaries, and $\mathrm{N}_{2}$ fluxes account for 15 to $70 \%$ of benthic $\mathrm{N}$ fluxes. Yoon \& Benner (1992) reported that 29 to $80 \%$ of the benthic nitrogen fluxes are in fact $\mathrm{N}_{2}$.

\section{Burial}

The sediment content of PON taken from Reschke (1999) and sediment accumulation rates from Gulin et al. (1997) provides a value of $377 \times 10^{3}{\mathrm{t} \mathrm{POC} \mathrm{yr}^{-1} \text { and }}^{3}$ $57 \times 10^{3} \mathrm{t} \mathrm{PON} \mathrm{yr}^{-1}$ buried in the sediments. Using these values and the mass balance estimates of gross sedimentation of POC and PON, shows that 6 to $16 \%$ and 8 to $17 \%$ of POC and PON to the sediments is buried, respectively. 


\section{Nitrogen budget of the shelf}

A nitrogen budget of the Black Sea shelf is now proposed based on the time and space integration of the EROS-21 measurements.

Looking at the proportions of the particulate matter reaching the sediments that is buried (Fig. 16b), shows that in the high flux region $\sim 16 \%$ of the POC and $\sim 17 \%$ of the PON remains in the sediments, $\sim 37 \%$ of the PON is recycled to ammonia, $\sim 5 \%$ leaves the sediment as nitrate and $\sim 51 \%$ of the nitrogen is lost by denitrification.

The nitrogen budget (Fig. 16) established on the basis of the mass balance calculations of the EROS-21 measured nitrogen fluxes is almost closed for the high flux area (with an error of $13 \times 10^{3} \mathrm{t} \mathrm{N}$ ), while in the low flux area, the error in the budget reaches $70 \times 10^{3} \mathrm{t} \mathrm{N}$. This can be explained by the overestimation in this region of the PON flux to the sediment because part of the oxygen might have been consumed by macrozoobenthos instead of for microbial aerobic decomposition of organic matter.

One can conclude that even if we could suspect that the total carbon flux to the shelf sediments has been overestimated by the integration of the EROS-21 measurements, the analysis of in situ observations and model results performed on the Black Sea's northwestern shelf reveals that the shelf acts as an efficient sink for riverine nutrients with, according to local measurements, $57 \times 10^{3} \mathrm{t} \mathrm{N} \mathrm{yr}^{-1}$ lost due to burial and $324 \times$ $10^{3} \mathrm{t} \mathrm{N} \mathrm{yr}^{-1}$ lost through denitrification. This represents about $50 \%$ of the annual load of total DIN discharged by the Danube.

Acknowledgements. This work was supported by the National Fund for Scientific Research, Belgium, and is a contribution to the INTAS project 99-01710. The first author is grateful to the EU for providing a Marie-Curie fellowship to enable her to spend $2 \mathrm{yr}$ at NIOO-CEME, Yerseke, The Netherlands. In 1998, the cruise was fully supported by EAWAG. We are grateful to the crew of RV 'Professor Vodyanitsky' and colleagues of the Institute of Biology of the Southern Seas, Sevastopol for skilful support during the 1997 and 1998 cruises. We further thank Chregu Dinkel, Gabriela Friedl and Sandra Steingruber for their support at sea. This is the MARE contribution 029.

\section{LITERATURE CITED}

Aller RC (1982) The effects of macrobenthos on chemical properties of marine sediment and overlaying water. In: McCall PL, Tevesz MJS (eds) Animal-sediment relations. Plenum Press, New York, p 53-102

Archer D, Devol A (1992) Benthic oxygen fluxes on the Washington shelf and slope: a comparison of in-situ micro electrode and flux chamber measurements. Limnol Oceanogr 37(3):614-629

Berner RA (1980) Early diagenesis: a theoretical approach.
Princeton University Press, Princeton, NJ, p 241

Betzer P, Showers W, Laws E, Winn C, DiTullio G, Kroopnick $P$ (1984) Primary productivity and particulate fluxes on a transect of the equator at $153^{\circ} \mathrm{W}$ in the Pacific Ocean. Deep-Sea Res I 31:1-11

Bouvier T (1998) Structure et dynamique du reseau trophique microbien dans le bassin nord occidental de la Mer Noire sous influence du Danube. PhD thesis, University of Brussels

Christensen JP, Murray JW, Devol AH, Codispoti LA (1987) Denitrification in continental shelf sediments has major impact on the ocean nitrogen budget. Global Biogeochem Cycles 1(2):97-116

Cipollini P, Barale V, Davidov A, Melin F (1999) Updated MOS bio-optical algorithms in the Northwestern Black Sea. In: Institute of Space Sensor Technology (ed) 3rd International Workshop on MOS-IRS and ocean colour. Wissenschaft und Technik Verlag, Berlin, p 93-100

Cociasu A, Diaconu V, Popa L, Buga L, Nae I, Doragan L, Malciu V (1997) The nutrient stock of the Romanian shelf of the Black Sea during the last three decades. In: Ozsoy E, Mikaelyan A (eds) Sensitivity to change: Black Sea, Baltic Sea and North Sea. NATO ASI Ser 2: Environment, Vol 27. Kluwer Academic, Dordrecht, p 49-63

Cramer A (1989) A common artifact in estimates of benthic community respiration caused by the use of stainless steel. Neth J Sea Res 23:1-6

Dauwe B, Middelburg JJ, Herman PMJ (2001) Effect of oxygen on the degradability of organic matter in subtidal and intertidal sediments of the North Sea. Mar Ecol Prog Ser 215:13-22

Delhez EJM, Campin JM, Hirst A, Deleersnijder E (1999) Toward a general theory of the age in ocean modelling. Ocean Modelling 1:17-27

Dettmann EH (2001) Effect of water residence time on annual export and denitrification of nitrogen in estuaries: a model analysis. Estuaries 24(4):481-490

Devol AH, Christensen JP (1993) Benthic fluxes and nitrogen cycling in sediments of the continental margin of the eastern North Pacific. J Mar Res 51:345-372

Epping EHG, Helder W (1997) Oxygen budgets calculated from in-situ oxygen microprofiles for Northern Adriatic sediments. Cont Shelf Res 17(14):1737-1764

Friedl G, Dinkel C, Wehrli B (1998) Benthic fluxes in the northwestern Black Sea. Mar Chem 62:77-88

Friedrich J, Dinkel C, Friedl G, Pimenov N and 5 others (2002) Benthic nutrient cycling and diagenetic pathways in the North Western Black Sea. Estuar Coast Shelf Sci 54(3): 369-383

Furrer G, Wehrli B (1996) Microbial reactions, chemical speciation and multicomponent diffusion in pore waters of an eutrophic lake. Geochim Cosmochim Acta 60(13): $2333-2346$

Graf G (1992) Benthic-pelagic coupling: a benthic view. Oceanogr Mar Biol Annu Rev 30:149-190

Grégoire M, Lacroix G (2003) Exchange processes and nitrogen cycling on the shelf and continental slope of the Black Sea basin. Global Biogeochem Cycles 17:42-1-42-17

Grégoire M, Nezlin N, Kostianoy A (2001) Modeling the nitrogen cycling and plankton productivity in an enclosed environment (the Black Sea) using a three-dimensional coupled hydrodynamical-ecosystem model. J Geophys Res (in press)

Gulin SB, Aarkrog A, Polikarpov GG, Nielsen SP, Egorov VN (1997) Chronological study of ${ }^{137} \mathrm{Cs}$ input to the bottom sediments to the Black Sea deep and shelf sediments. Radioprotection 49(4):319-328 
Hargrave B (1973) Coupling carbon flow through some pelagic and benthic communities. J Fish Res Board Can 30:1317-1326

Heip C, Goossen N, Herman P, Kromkamp J, Middelburg J, Soetaert K (1995) Production and consumption of biological particles in temperate tidal estuaries. Oceanogr Mar Biol Annu Rev 33:1-149

Hulthe G, Hulth S, Hall POJ (1998) Effect of oxygen on degradation rate of refractory and labile organic matter in continental margin sediments. Geochim Cosmochim Acta 62: $1319-1328$

Kristensen E (1988) Benthic fauna and biogeochemical processes in marine sediments: microbial activities and fluxes. In: Blackburn T, Sorensen J (eds) Nitrogen cycling in coastal marine environments. Scope, Wiley, p 275-299

Kristensen E, Ahmed SI, Devol AH (1995) Aerobic and anaerobic decomposition of organic matter: which is fastest? Limnol Oceanogr 40:1430-1437

Lerman A (1979) Geochemical processes: water and sediment environments. Wiley Interscience, New York, p 481

Manheim FT (1970) The diffusion of ions in unconsolidated sediments. Earth Planet Sci Lett 9:307-309

Martin JH, Knauer G, Karl D, Broenkow W (1987) VERTEX: carbon cycling in the northeast Pacific. Deep-Sea Res 34: $267-285$

Nezlin N, Kostianoy A, Grégoire M (1999) Patterns of seasonal and interannual changes of surface chlorophyll concentration in the Black Sea revealed from the remote sensed data. Remote Sens Environ 69:43-55

Oguz T, Ashwini G, Deshpande G, Malanotte-Rizzoli P (2002) On the role of mesoscale processes controlling biological variability in the Black Sea: inferences from SeaWIFSderived surface chlorophyll field. Cont Shelf Res 22:1477-1492

Popa A (1993) Liquid and sediment inputs of the Danube river into the north-western Black Sea. Mitteilungen aus dem Geologisch-Paleontologischen Institut der Universität

Editorial responsibility: Victor de Jonge (Contributing Editor), Haren, The Netherlands
Hamburg 74:137-149

Ragueneau O, Lancelot C, Egorov V, Verlimmeren J, Daoud N, Rousseau V, Popovichev V, Brion N (2002) Present-day biogeochemical transformations of inorganic nutrients in the Danube-north-western Black Sea mixing zone. Estuar Coast Shelf Sci 54(3):321-336

Reschke S (1999) Biogeochemistry of suspended matter in the Danube and its influence on the sedimentation of the north-western Black Sea. PhD thesis, University of Hamburg

Seitzinger SH (1988) Denitrification in freshwater and coastal marine ecosystems: ecological and geochemical significance. Limnol Oceanogr 33(4):702-724

Sur H, Ozsoy E, Unluata U (1994) Boundary current instabilities, shelf mixing and eutrophication processes in the Black Sea. Prog Oceanogr 33:249-302

Tengberg A, De Bouvee F, Hall P, Berelson W and 26 others (1995) Benthic chamber and profile landers in oceanography-a review of design, technical solutions and functioning. Prog Oceanogr 35:265-294

Ullman WJ, Aller RC (1982) Diffusion coefficients in nearshore marine sediments. Limnol Oceanogr 27(3):552-556

Urban NR, Dinkel C, Wehrli B (1997) Solute transfer across the sediment surface of a eutrophic lake: I. Porewater profiles from dialysis samplers. Aquat Sci 59:1-25

Wijsman J (2001) Early diagenetic processes in northwestern Black Sea sediments. PhD thesis, Netherlands Institute of Ecology, Yerseke

Wijsman J, Herman P, Gomoiu MT (1999) Spatial distribution in sediment characteristics and benthic activity on the northwestern Black Sea shelf. Mar Ecol Prog Ser 181:25-39

Wollast R (1998) The global coastal ocean. Processes and methods. In: Brink KH, Robinson AR (eds) The sea, Vol 10 John Wiley and Sons, New York, p 213-252

Yoon WB, Benner R (1992) Denitrification and oxygen consumption in sediments of two south Texas estuaries. Mar Ecol Prog Ser 90:157-176

Submitted: August 14, 2002; Accepted: October 7, 2003

Proofs received from author(s): April 2, 2004 